Florida International University FIU Digital Commons

FIU Electronic Theses and Dissertations

University Graduate School

11-16-2005

\title{
Dynamics of canopy cover in a wet forest in Costa Rica
}

Carolina Brinez

Florida International University

DOI: $10.25148 /$ etd.FI14051839

Follow this and additional works at: https://digitalcommons.fiu.edu/etd

Part of the Biology Commons

\section{Recommended Citation}

Brinez, Carolina, "Dynamics of canopy cover in a wet forest in Costa Rica" (2005). FIU Electronic Theses and Dissertations. 1884. https://digitalcommons.fiu.edu/etd/1884

This work is brought to you for free and open access by the University Graduate School at FIU Digital Commons. It has been accepted for inclusion in FIU Electronic Theses and Dissertations by an authorized administrator of FIU Digital Commons. For more information, please contact dcc@fiu.edu. 


\title{
FLORIDA INTERNATIONAL UNIVERSITY
}

Miami, Florida

DYNAMICS OF CANOPY COVER IN A WET FOREST IN COSTA RICA

\author{
A thesis submitted in partial fulfillment of the \\ requirements for the degree of \\ MASTER OF SCIENCE \\ in \\ BIOLOGY \\ by
}

Carolina Brinez

2005 
To: Interim Dean Mark D. Szuchman

College of Arts and Sciences

This thesis, written by Carolina Brinez, and entitled Dynamics of Canopy Cover in a Wet Forest in Costa Rica, having been approved in respect to style and intellectual content, is referred to you for judgment.

We have read this thesis and recommend that it be approved.

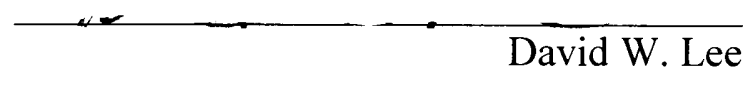

Michael S. Ross

Date of Defense: November 16, 2005

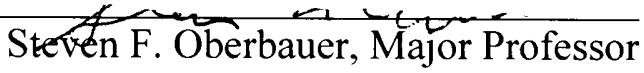

The thesis of Carolina Brinez is approved.

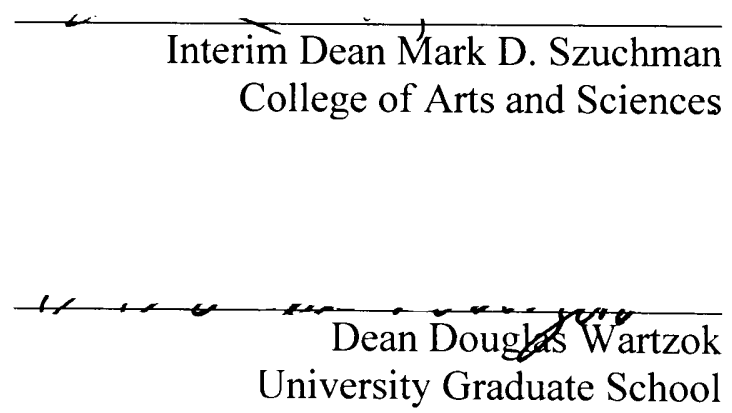

Florida International University, 2005 


\section{DEDICATION}

I dedicate this thesis to my mother who was my closest friend and who taught me the meaning of love and perseverance in good and bad times. Without her love, patience and encouragement, the completion of this work would not have been possible. 


\section{ACKNOWLEDGMENTS}

I would like to acknowledge my major professor Steven F. Oberbauer, my committee members Michael S. Ross and David W. Lee. I thank Florida International University, Maureen Donnelly graduate program director and all the faculty members of the Department of Biological Sciences, Deborah and David Clark and the Organization for Tropical Studies. Special acknowledgement to Chad E. Husby for his valuable expertise with $\mathrm{S}+$ and SAS for the statistical analysis of my data. I would also like to acknowledge my lab fellows in the Global Change and Ecophysiology Laboratory: Andrea Garcia, Daniel Gomez, Flavio Moreno, Paulo Olivas, Danielle Pallow and Kevin Whelan. Special thanks to my husband Hanna, my father, Efraim, my siblings Maristella, Monica and Douglas for their love, patience and support, throughout these 2 years of hard work that kept me from sharing more valuable time with them. 
ABSTRACT OF THE THESIS

DYNAMICS OF CANOPY COVER IN A WET FOREST IN COSTA RICA

by

\section{Carolina Brinez}

Florida International University, 2005

Miami, Florida

Professor Steven F. Oberbauer, Major Professor

I examined the effects of soil and slope conditions on canopy dynamics in terms of openness and leaf area index through time as measured by hemispherical photography. Specifically, I compared alluvial versus residual soil and slope versus plateau and flat plots in an old-growth tropical wet forest in Costa Rica. No significant effects of slope were found for any estimator of canopy coverage in any analysis. Soil type approached significance as a single factor and several soil*year interactions were highly significant. In addition, I found highly significant inter-annual variation in all analyses that was concordant on all plot types. This is the first long-term study to document substantial inter-annual variation in canopy cover for a tropical wet forest. These patterns are a combination of seasonal changes in leaf area, forest dynamics resulting from gap formation and closure, and inter-annual variation in leaf area coverage caused by climate variation. 


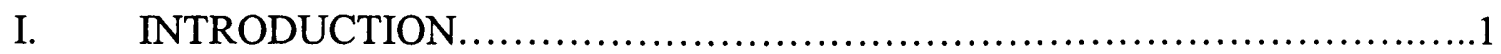

Objective and Hypothesis..................................................

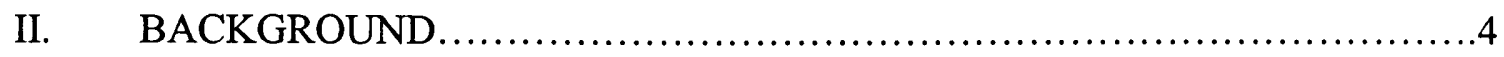

Gaps..................................................................

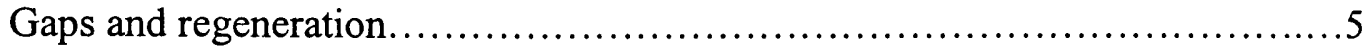

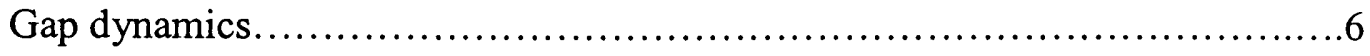

Gap formation.....................................................

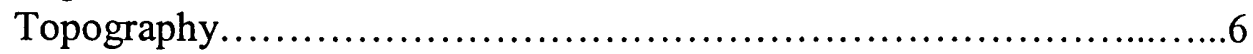

Soil type.......................................................... 8

Gap closure.......................................................

LAI and canopy openness.................................................. 10

Measurement of canopy dynamics.......................................11

LAI and openness from hemispherical photos..............................14

III. METHODS ............................................................ 16

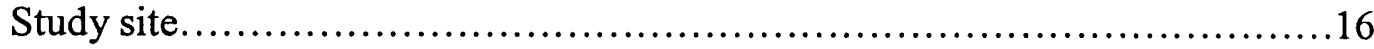

Sample design.................................................... 16

Photographic methods................................................... 17

Photographic Analysis................................................... 18

Data analysis.............................................................

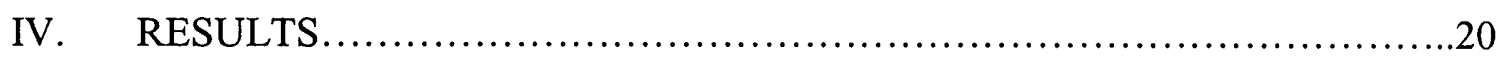

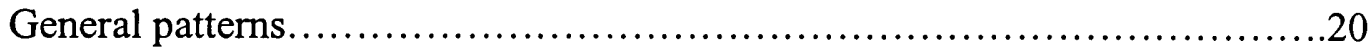

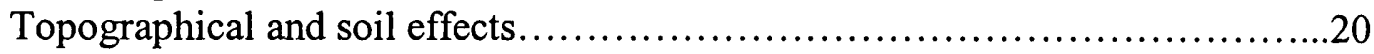

Static comparisons..............................................20

Dynamic comparisons.........................................21

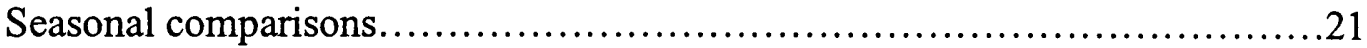

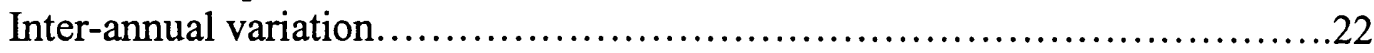

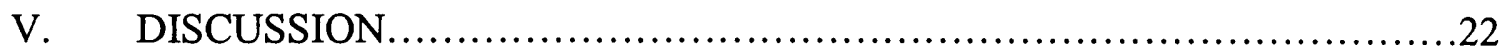

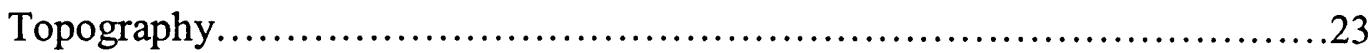

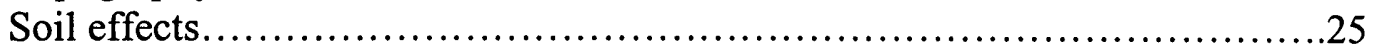

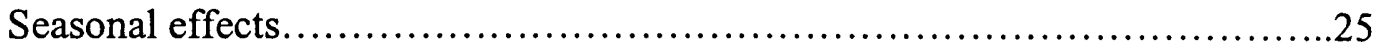

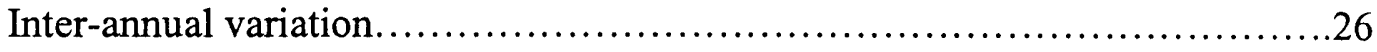

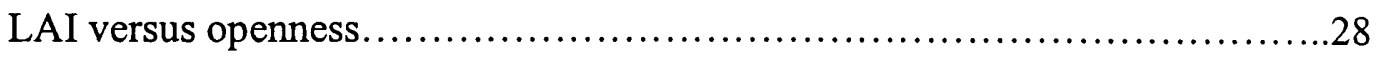

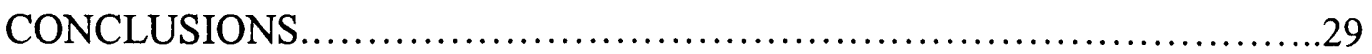

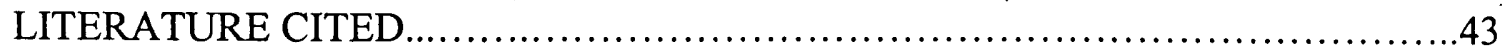




\section{LIST OF FIGURES}

FIGURE

PAGE

1. Location of study plots within soil types at La Selva, Costa Rica

2. Measurement of canopy openness and LAI for the three plot types studied in an old growth forest in Costa Rica for the dry and wet seasons....

3. Canopy openness and leaf area index for wet and dry season for the three plot types described in figure 2

4. Mean values of canopy openness and leaf area index for the flat vs slope relationship for dry season and wet season.

5. Mean values of canopy openness and LAI for the flat vs slope relationship for the dry and wet season.

6. Dynamics: values of canopy openness and LAI for the flat vs slope and the alluvial vs residual relationship for the dry and wet seasons

7. Patterns of intra and inter-annual variation in openness and LAI.

8. Mean seasonal LAI and rainfall in dry and wet seasons

9. Mean seasonal LAI and maximum and minimum temperature in dry and wet seasons

10. Relationship between openness and LAI 


\section{INTRODUCTION}

Forest canopy openings are a critical requirement for regeneration of many canopy tree species (Schemske \& Brokaw 1982, Orians 1982, Bazzaz 1983, Marquis et al 1986, Denslow 1990, Harshorn 1980), and provide one of the few rain forest habitats for many pioneer species (Garwood et al 1979, Uhl \& Murphy 1982, Putz 1983, Clark \& Clark 1990). According to Valverde (1997), gaps provide a permanently recurring source of environmental heterogeneity, which allows the coexistence of species with different life histories and ecological requirements thus increasing community diversity. Gap dynamics involves a disturbance-regrowth cycle, which is of ecological interest in itself (Denslow 1988). Because of the importance of gaps for sapling regeneration and therefore the ability of a species to persist in an area, the study of gap-phase regeneration provides insight into species adaptations and overall patterns of forest species composition and growth (Runkle and Yetter 1987). In fact, Brokaw (1985) argued that to interpret forest composition and dynamics one must study regrowth in gaps of different sizes. At La Selva, Costa Rica as many as $75 \%$ of canopy tree species are thought to be dependent on canopy openings of various sizes for successful regeneration (Hartshorn 1980).

The ways in which trees die cause different types of gaps. When trees die standing, they cause small gaps that favor shade-intolerant species or branch extension from neighboring trees (Krasny \& Whitmore 1992). Trees that uproot or snap often fall onto their neighboring trees and cause large gaps Brokaw (1985) and favor pioneer or shade intolerant species. 
As argued by Lieberman \& Lieberman (1995), studies of gap dynamics and changes in canopy closure conditions over time are essential to evaluate the responses of trees in terms of growth and mortality. Understanding which are the variables that limit tree growth over different spatial and temporal scales is important for understanding the mechanisms that determine species distributions. Canopy dynamics until recently have been largely treated as a static property of forests, but there is no a priori reason to think that large differences in spatial and temporal variation do not occur.

For instance, recent studies have noted important differences in tropical forest structure and composition in response to soil type and slope position (Clark \& Clark 2002, Clark et al 2004). The forest tract at La Selva Biological Station in Costa Rica includes both rich alluvial soils and poor residual soils. More fertile soils have been linked with shallower roots contributing to increased frequency of tree fall gaps (Grubb 1977, Kapos 1990, Ostertag 1998). The moisture content and cohesive properties of the different soil types may also have important effects on the dynamics of a forest. Slopes as opposed to flat and plateau conditions may also have an effect on tree canopy dynamics, because tree roots and buttresses on slopes are positioned at an angle, potentially making them less stable.

Most canopy studies have been short term; none of the previous studies have followed dynamics of individual gaps for more than 5 years. The 7-year study presented here should be very helpful in understanding temporal variation in forest dynamics. 


\section{OBJECTIVE AND HYPOTHESES}

The objective of this study was to examine the effects of soil and slope conditions on canopy dynamics in terms of openness and leaf area index (LAI) through out time as measured by hemispherical photography. Specifically, I compared alluvial versus residual soil and slope versus plateau and flat plots in an old-growth tropical wet forest in Costa Rica. Within this framework I tested the following hypotheses:

\section{HYPOTHES 1}

Canopy cover will be more dynamic on slopes compared to flat plots. Greater canopy dynamics should be apparent both as higher average canopy openness (and lower LAI) as well as greater temporal variation.

Trees are in a less stable position on slopes than on flat terrain, and landslips are also more common on steep slopes. At La Selva, plots had a higher density of small stems on slopes compared to flat terrain, suggesting that turnover rates are highest on slopes (Clark \& Clark 2000). As water and nutrients move downhill, trees near the bottom of slopes may have lower investment in roots than trees on plateaus or upper slopes.

\section{HYPOTHES 2}

Canopy cover will be more dynamic on alluvial rather than on residual soils. Recent studies suggest that in rich soils lower biomass is allocated to roots. Shallow rooting on rich soils increase the likelihood of treefalls, while the rich soil conditions promote more rapid growth of colonizing trees and shrubs. 


\section{BACKGROUND}

In the broad sense canopy dynamics refers to the changes in canopy cover on many scales of space and time. In general usage, canopy dynamics refers to gap formation following a disturbance and gap closure as recovery from the disturbance occurs. However, seasonal forests such on Barro Colorado Island, Panama, canopy coverage changes substantially as dry season deciduous species lose their leaves for extended periods. In less seasonal forests such as La Selva, dry season declines in canopy cover may be less apparent and highly variable. Finally, canopy coverage may vary from year to year although, there is currently no data for or against large inter-annual variation.

\section{GAPS}

Forest disturbances create gaps that can be classified as fine and coarse scale (Spies \& Franklin 1989). Coarse scale disturbances which include wildfire, wind and volcanic eruptions typically create gaps of 0.1 to $>100,000$ ha in the forest while fine scale events include lightning, windthrow and single tree death, create gap openings of less than 0.1 ha. Mean gap size in canopies in old growth forest at La Selva is $161 \mathrm{~m}^{2}$ (Sanford et al 1986) and both proximity to existing gaps and bigger crown size are associated with larger gap sizes (Hubbell \& Foster 1986, VanderMeer 1996a). Gap closure may be due to growth of trees from the sides of the gap or by growth from the understorey.

Models of gap regeneration have been important tools for understanding forest composition, distribution and succession under existing climate conditions and have been 
applied in many systems (Shugart 1998). Above ground growth and competition have been the most well-developed aspect of gap models (Bugmann 2001).

\section{GAPS AND REGENERATION}

Low light levels predominate in the forest understorey but they quickly change into higher light levels when a tree or a branch falls. Gaps caused by the death of one or more canopy trees in a forest change the light environment drastically (Chadzon \& Fetcher 1984, Canham et al 1990, Chazdon and Pearcy 1991, Whitmore et al 1993; Bazzaz and Wayne 1993, Denslow et al 1998, Van Pelt and Franklin 1999, McGuire et al 2001), in a mosaic first recognized by Aubreville (1938).

Light penetration depends on the intensity of incident light and upon the number, size, as well as the spatial distribution of canopy openings (Anderson 1964, Reifsnyder et al 1971, Hutchinson \& Matt 1977, Brokaw 1985, Brokaw \& Busing 2000). Crown traits such as leaf area determine the carbon gain of the whole plant, in interaction with light levels received by leaves and the ability to convert light to plant assimilates. Thus, crown traits responses and light fluctuations associated with gap opening and closing might influence future growth and survival of understorey seedlings and saplings (Canham \& Marks 1985, Norman \& Martin 1993, Sterck et al 2001).

Four life history patterns characterize the 45 most abundant tree species $\geq 10 \mathrm{~cm}$ dbh in the La Selva permanent plots (Lieberman et al 1985, Lieberman \& Lieberman 1995): (1) slow maximum growth and short life-spans (understory tree species), (2) slow maximum growth and longer life spans (subcanopy species), (3) rapid maximum growth and long life-spans (canopy and subcanopy species), and (4) very rapid maximum growth 
and very short life-spans (canopy and subcanopy species). "The range of growth behavior among species may thus be considered a bivariate continuum based upon growth and projected life-span" (Lieberman et al. 1985). These growth patterns are related to patterns of shade tolerance, and hence the study of gap dynamics via changes in LAI canopy closure is of great importance. Furthermore, as seen in Clark \& Clark (1994), photosynthetic active radiation (PAR) differs significantly within and among years at La Selva. Ecosystem productivity studies in South America imply that PAR controls productivity of wet forests, and additional study of growth, and survivorship and distribution are needed to determine if species utilize light in a different manner at La Selva.

\section{GAP DYNAMICS}

Gap formation

Topography Slope appears to play an important role in changes in canopy cover over time. In the lowland wet forest of La Selva, Costa Rica, Hartshorn (1980) found differences in gap area among plateau, steep slopes and rolling slopes. Clark et al (1998) found that certain species preferred the ridge tops (flat terrain) and lower parts of the slope rather than the base of the slopes. In three Bornean rain forests, Gale (2001) examined factors determining tree growth and death and found slope position (valley, mid-slope, upper slope or ridge) was related to mode of tree death in all three forests. In addition, he concluded that the proportion of trees dying standing was highest in the valleys and lowest on the ridge tops, while uprooting had the opposite relationship. Slope 
position, though, had little effect on the proportion of snapped trees. In the Hoja Blanca Hills, western Ecuador, Gale (1999) studied tree death at a lowland rain forest and using regression analysis found that slope strongly related to mode of death. It was concluded that uprooting and snapping resulted from the steep terrain and high precipitation. The distribution of uprooted and snapped trees was found to be clumped while trees that died standing were distributed at random. In their study of canopy gaps in primary forest at Nouragues, French Guiana, Van der Meer and Bongers (1996b) found that uprooting of trees was related to the shallow soils found on slopes. Many other trees fell when a tree uprooted, independent of the diameter of the uprooted tree. Also, in a tropical moist forest of the Ivory Coast, Poorter et al (1994) found larger gaps on the upper and middle slope and mean gap density and percentage area significantly larger at upper slope positions compared to the valley bottom. They suggested that wind could also play a disturbance role and interact with slope since wind is more effective at an upper portion of the slope than in a valley. They also argued that trees were larger on the higher slope and thus that the size of the treefall gaps were as well. Ashton (1995) found that understory survival was less on the ridgetop than on the valley and midslope sites. He argued that seedling survival in gaps was associated with a greater predisposition to drought because of the drier soils found on the ridgetop. He speculated that the largest and most frequent disturbances occur in valleys and lower slopes due to multiple windthrows, while single tree deaths due to lightning or droughts are more common on ridgetops. In addition, Aiba (2004) found mean growth rates at $10-40 \mathrm{~cm}$ diameter and size distributions of species were not related to topographic associations. 
Soil type Soil physical and chemical properties are known to be an important factor responsible for canopy changes in cover including gap formation (Hartshorn 1980, Brokaw 198, Denslow 1986). In a 200-m mountain slope in a temperate deciduous forest, Tateno \& Takeda (2003) found differences in soil nitrogen and light availability between the upper and lower parts of a slope. They maintain the valley (lower part of slope) may be light limited while the ridge (upper part of slope) may be soil $\mathrm{N}$ limited. At the University of California Sedgwick Natural Reserves, Gessler et al (2000) argued that convex slopes are more infertile than concave slopes and found that soil conditions such as soil fertility and moisture in slope conditions might affect convex sites even more than light conditions. In an old growth subtropical evergreen forest in south-western Japan Enoki \& Abe (2004) assumed slope steepness corresponded to surface soil stability, and identified sites preferences along a gradient from unstable fertile sites to stable infertile sites.

According to Kapos (1990), soil type may affect gap formation through effects on the effectiveness of root systems for anchoring trees. Furthermore, La Selva primary forest in Costa Rica, Ostertag (1998) found differences between infertile and fertile soil types in the amount of root length and biomass and in root proliferation responses. These results suggest that the consequences of gap formation may be dependent on background levels of soil fertility. Vitosek and Denslow (1986) found that at very dynamic primary forests such as La Selva, Costa Rica and Barro Colorado, Panama, gap sites are most commonly found on nutrient rich alluvial soils. On the other hand, Grubb (1977) found that at areas with low occurrences of gaps, such as montane rain forests, gaps tend to occur in poorer soils. 
Gap closure

Gap closure occurs via regeneration either by trees of the same species, by succession when trees occupying the gaps are of different species and by branch extension of surrounding trees. Colonists of a forest gap either disperse into it or are already present when the disturbance opens the canopy. If a gap is produced by a very intense disturbance that removes all organisms including buried seeds, then all colonists must originate from outside the gaps. On the other hand with less intense disturbances such as treefalls, buried seeds, seedlings, saplings, and trees are able to survive the disturbance (Connell \& Lowman 1989). In addition as per Denslow (1987), being present on a site before or soon after a gap is created results in a large advantage over later arrivals, For instance, Uhl et al (1988) found gap closure to occur by regrowth of trees that survived treefalls or by lateral expansion of nearby trees. In his study of vegetation dynamics of an old growth forest in Venezuela, he observed that 4 years after gap formation, $87 \%$ of the trees $>1 \mathrm{~m}$ tall in small gaps originated from seedling banks. He also found that in treefall gaps, shorter plants grew much slower than taller ones and suggested newly established seedlings originating from buried and dispersed seeds were less likely to be a significant component of the trees occupying the gaps. In addition, Brokaw (1985) found that successful stems were all established prior to or within 1 to 3 years following gap formation. As stated in Whitmore (1989), it seems that the great majority of tropical forest species are present before gaps form (Hubbel and Foster 1986, Brokaw 1989). Satake et al (2004) suggested that gap closure is affected by neighboring gap sites. If gaps are near trees instead of other gap areas there is a greater chance that surrounding trees may extend big branches and fill the gap. Schlich and Iwasa (2004) also found gap 
recovery depends on the neighborhood trees at Barro Colorado Island, Panama. Horvitz \& Schemske (1986) estimated it takes about 10 years for full canopy closure to occur and Cipollini et al (1993) reported an estimate of 8 years for full canopy closure to occur. Runkle (1981) argued the maximum time needed for a gap to close is $10-40$ years, a combination of the maximum time required for saplings to reach $10-20 \mathrm{~m}$ in height and the time needed for lateral extension by adjacent trees. Most importantly, gap formation as well as canopy closure have important consequences by imposing times and rates on ecological processes, as argued by Brokaw (1982), Busing (1996) and Valverde (1997).

\section{LAI AND CANOPY OPENNESS}

The most common estimates of canopy coverage are leaf area index (LAI) and Openness. LAI, defined as the amount leaf area per unit ground area, is an important example of canopy crown architecture information that helps to link canopy structure and function. Leaf area is the main factor controlling light absorption by plant canopies (DeLucia et al 2002), and according to Beer's law there is an exponential decrease of light with increasing LAI. Hence, accurate measurements of forest LAI are essential to estimate light at the ecosystem level. LAI is the most common and possibly, the most valuable comparative measure of foliage quantity (Waring 1985, Parker 1995) over time, under different environmental conditions or among species. In fact, Waring (1985) suggested that LAI is a useful structural characteristic to monitor for detection of early symptoms of natural and anthropogenic stresses on forest ecosystems. The amount of foliage contained in plant canopies is one basic ecological characteristic indicating the integrated effect of factors such as microclimate conditions and nutrient dynamics (Asner 
et al 2003). LAI is thus a critical parameter in physiology-based models of forest responses to global environmental change (Potter et al 1993, Sellers et al 1995, Kimball et al 1997, Running et al 2000, Nemani et al 2003). Many studies have measured spatial and temporal variations in LAI $\left(\mathrm{m}^{2} \mathrm{leaf} / \mathrm{m}^{2}\right.$ ground) and leaf characteristics in forest ecosystems (Pierce and Running 1988, McWilliam et al 1993, Reich et al 1999). LAI varies greatly among ecosystems, ranging from less than 1 in arid ecosystems, up to 20 $\mathrm{m}^{2}$ in some conifer stands (Kozlowski et al 1991). LAI also varies within ecosystems depending on site conditions.

Openness also known as canopy cover is defined as the total amount of open sky over a given part on the forest floor. Canopy openness is commonly used for tree survivorship studies as seen in Kobe et al $(1995,1996,1997)$ and similar to LAI the results are comparable to long-term sensor measurements (Rich et al 1993, Comeau et al 1998). LAI as well as other light parameters are linearly or logarithmically related to openness so it can be used when LAI information is lacking. Openness, similar to LAI, is not influenced by the location of study site and is not identical to vegetation cover, which is a horizontal projection of plant cover.

\section{MEASUREMENT OF CANOPY DYNAMICS}

Hemispherical photography has been extremely useful for measuring changes over time in forest light environments (Anderson 1964, Chadzon and Field 1987, Pearcy 1989, Canham et al 1990, Rich et al 1993, Whitmore et al 1993, Palik et al 1997, Comeau et al 1998) by the estimation of canopy parameters such as canopy openness and percent transmission. Estimates are comparable with long-term quantum sensor measurements 
(Rich et al 1993, Comeau et al 1998). The technique involves taking photographs looking upward from beneath a canopy through a $180^{\circ}$ lens, which permits direct measurement of canopy openings and estimation of light transmittance. Light penetration through the canopy depends on the intensity of incident light and upon the number, size, and spatial distribution of canopy openings (Anderson 1964, Reifsnyder et al 1971, Hutchinson \& Matt 1977, Brokaw 1985, Brokaw \& Busing 2000). Consequently, hemispherical canopy photographs can be used to quantify both the status of the canopy and light levels for a particular understory location. In this study I used leaf area index (LAI) and canopy openness from hemispherical photographs as metrics of canopy change.

Direct measurements of LAI involve destructive harvesting, which is undesirable in protected areas and in long-term studies. Semi-direct methods require allometry based on physical dimensions such as stem diameter at breast height and using species or stand specific relationships. Indirect methods include photosensitive instruments and transformation into LAI by a calibrated relationship. Several instruments, such as the Sunfleck Ceptometer and ACCUPAR (Decagon Devices, Pullman, WA, USA), LAI2000 Plant Canopy Analyzer (LI-COR, Lincoln, NE, USA), and DEMON (CSIRO, Center for Environmental Mechanics, Canberra, Australia), TRAC (Tracing Radiation and Architecture of Canopies), MVI (Multi-band imager) and hemispherical photography use canopy light interception to estimate leaf area optically, thereby speeding LAI determination and avoiding destructive tree harvests. All these instruments assume foliage is randomly distributed in the canopy and the canopy gap or sky fraction can be measured over a range of zenith angles (Fassnacht et al 1994; Chen et al 1997). The 
Ceptometer and DEMON require numerous measurements at different zenith angles, while the other instruments obtain multiple measurements of the extinction coefficient at different angles simultaneously (Welles 1990; Chen and Cihlar 1995; Chen et al 1997, Kucharik et al 1997). The TRAC and the MVI are sufficiently complex that most scientists are not likely to use them routinely (Gower et al 1999).

Hemispherical photography is the most widely applied method to calculate LAI indirectly. Multitemporal satellite derived data is the latest technique to assess these parameters but disadvantages include that satellites cannot measure how tall the vegetation is, cannot be used in cloudy days and are extremely expensive. Synthetic aperture radar (SAR) overcomes some of these disadvantages but the footprint size is not appropriate for fine scale structures. Remote sensing technology such as light detection and ranging (LIDAR) are able to detect vegetation structure with great detail (Ritchie et al 1993), and small foot-print multiple-return LIDAR systems should be able to detect the horizontal and vertical distributions of forest canopies (Means 2000). Parker (2005) has recently developed an upward-looking backpack LIDAR system that holds great promise.

Estimates of LAI derived from optical instruments can suffer from two sources of error: 1) nonrandom distribution of foliage in the canopy and 2) radiation interception by wood elements (Gower et al, 1999). Some debate has taken place on whether the canopy total woody area values should be subtracted from LAI estimates derived with optical instrumentation (Deblonde et al 1994; Chen et al 1997). Tree stem and branches may or may not contribute significantly to the interception of light in canopies, depending on the forest species and stage of leaf-out, senescence or defoliation due to disease (Gower et al 1999). 


\section{LAI AND OPENNESS FROM HEMISPHERICAL PHOTOS}

There are several software programs that estimate LAI as well as openness, such as Gap Light Analyzer (Sallaway, Victoria, British Columbia) and WINPHOT (Ter Ter Steege, Georgetown, Guyana), HEMIVIEW (Dynamax, Dallas, Texas), SCANOPY (Regent Instruments, Cananda) among others. Photosyntheis and other indirect measurements of LAI are based on the determination of gap fractions in the foliage (Norman \& Campbell, 1989; Welles \& Norman, 1991). The program assumes leaves are small, randomly distributed, have no azimuthal preference and do not transmit light. In this study, WINPHOT (Ter Ter Steege 1996) was used to estimate LAI and canopy openness from canopy photographs. Because the basic calculations of all the programs are similar below I describe the functions of WINPHOT as a representative example.

"WINPHOT estimates LAI values up to 4 excellently; values up to 6 well with a slight underestimation, but values up to 8 are strongly underestimated. Some corrections should also be made for stem and branch area on the photos. Comparing LAI during leafy periods vs. leafless periods could help estimating the error as well as comparing tropical forests of similar stand structure (Ter Steege 1992). "WINPHOT calculation of openness is prone to the least ambiguities of all parameters and the program calculates openness precisely up to a canopy cover of $99.5 \%$ providing the images are of good quality (Ter Steege 1996)." LAI is determined from the gap fractions in the foliage. The gap fraction in the zenithal view angle $\mathrm{z}$ can be related to LAI. In addition, WINPHOT considers that the vegetation consists of (n) small layers of horizontal leaves which all make an equal part of the total LAI. Each layer has a partial leaf area of L=LAI/n and the chance of a light beam not being intercepted by such layer is $1-\mathrm{L}$ so after $\mathrm{n}$ layers the 
chance of light not being intercepted becomes $(1-\mathrm{L})^{\mathrm{n}}$ or the total light intensity relative to that above the canopy after $n$ layers is:

$$
\mathrm{I}(\mathrm{n})=\mathrm{I}(0) *(1-\mathrm{L})^{\mathrm{n}}
$$

which in exponential form is:

$$
\mathrm{I}(\mathrm{i})=\mathrm{I}(0) * \mathrm{e}^{[\mathrm{n} * \ln (1-\mathrm{L})]}
$$

or in the form of Monsi \& Saeki (1953)

$$
\mathrm{I}(\mathrm{i})=\mathrm{e}^{\left(-\mathrm{K}^{*} \mathrm{LAI}\right)}
$$

The gap fraction at a given angle is highly dependent on the leaf angle distribution. Vegetation with nearly vertically arranged leaves will show a high gap fraction at $\mathrm{z}=0$ degrees, while vegetation with horizontally arranged leaves and a similar LAI will show a much lower gap fraction at this angle. The gap fraction (T) at $z=67.5$ degrees is little affected by leaf angle (Bonhomme \& Chartier 1972, Norman \& Campbell 1989, Welles \& Norman 1991) and is related to LAI (Bonhomme \& Chartier 1972) as:

$$
\mathrm{LAI}=1.1 *-\ln [\mathrm{T}(67.5)]
$$

Openness is a measure of the total cover of the sky hemisphere. WINPHOT considers the projection of the sky hemisphere to consist of 90 concentric rings, dividing the main radius ( $\mathrm{R}$ ) in 90 parts and each ring corresponds to a circular sphere segment in the sky hemisphere with an arc of 1 degree. However, because the first ring may include a part of the circle that identifies the image boundary WINPHOT uses 89 circles instead of 90 . To obtain canopy cover from a hemispherical photograph cover is calculated for each of the 90 rings with corrections for the actual area of that segment on the sky hemisphere. The area [A] on a sphere segment defined by a lower angle al and an upper angle $\mathrm{a} 2$ is given by: 


$$
\mathrm{A}(\mathrm{a} 1-\mathrm{a} 2)=2 \mathrm{pi} * \mathrm{R} 2(\sin \mathrm{a} 2-\sin \mathrm{a} 1)
$$

Since the total hemisphere has an area of $2 \mathrm{pi}^{*} \mathrm{R}^{2}$, the fraction of the sky given by each of the rings is given by:

$$
A(a)=\sin (a+0.5)-\sin (a-0.5)
$$

The total canopy cover of a site is obtained by the sum of the cover fractions [C(a)] per circle multiplied by their part in the sky fraction as:

$$
\text { Canopy cover }=\operatorname{Sum}[\mathrm{C}(\mathrm{a}) * \mathrm{~A}(\mathrm{a}) / \mathrm{A}(\mathrm{tot})]
$$

\section{METHODS}

\section{STUDY SITE}

The study took place at the primary tropical wet forest at the Organization for Tropical Studies La Selva Biological Station in northern Costa Rica located at $10^{\circ} 26^{\prime} \mathrm{N}$, $84^{\circ} 00^{\prime} \mathrm{W}$ (Holdridge et al 1967, Hartshorn 1983). The mean monthly temperature at this Atlantic lowland site is $25.8{ }^{\circ} \mathrm{C}$ and annual precipitation is $3900 \mathrm{~mm} / \mathrm{yr}$ with no month averaging less than $100 \mathrm{~mm}$ (Sandford et al 1994). Elevation ranges from 36 to $135 \mathrm{~m}$ with some slopes approaching 70\% (Hartshorn 1983). Approximately 130 tree species are found in the canopy of the mature forest, which is comprised of $30-40 \mathrm{~m}$ tall trees and some reaching $55 \mathrm{~m}$ (Hartshorn 1983).

\section{SAMPLE DESIGN}

Within the old-growth forest at La Selva, 180.5 ha plots $(50 \times 100 \mathrm{~m})$ were established by the Carbono project (www.carbono.org) in 1997 in a stratified random design using the soils (Sancho \& Mata 1987) and topography (OTS unpublished data) coverages of La Selva (Figure 1). The study site included six plots on flat alluvial 
conditions (A for alluvial plots), six plots on flat residual sites ( $\mathrm{L}$ for Loma plots) and six plots on slope residual sites (P for Pendiente). Three of the plots on slopes are located in a NW aspect, and the remaining three plots on SE aspect. Plot size was based on the results of preliminary sampling to estimate the relation between plot area and variance in total basal area (Clark and Clark 2000, www.carbono.org). Plot size of $5000 \mathrm{~m}^{2}$ is far greater than the average gap size.

The 18 plots are gridded every $10 \mathrm{~m}$ with permanent rebar markers. Using these grid points, six points per plot were randomly selected without replacement as the positions for the time series of hemispherical photographs. Edge points were included. A total of $18 \times 6$ points $=108$ were photographed in each sampling period. Because tree mortality is $2-4 \%$ at La Selva (Liebermann et al 1994, Clark et al unpublished data) and the plots have 200-300 trees $>10 \mathrm{~cm}$ dbh, that means an average of 4-12 trees die each year per plot, many of them as treefalls. Consequently, a large number of gaps were encountered within the sample points over the study period. Dry season photographs were taken in January to April and wet season photographs in June to August.

\section{PHOTOGRAPHIC METHODS}

Canopy photographs were taken twice a year during the wet and dry seasons from 1998 to 2004 following the same techniques each sampling period. Photos were taken using a Nikon FM2 camera with databack using Kodak TRI-X 400 film and red filter with an $8 \mathrm{~mm}$ Nikon fisheye lens. The camera was mounted horizontally on a tripod at $1.5 \mathrm{~m}$ height over the rebar grid stakes for stakes less than $1.5 \mathrm{~m}$ and adjacent to the rebar when the stakes are taller than $1.5 \mathrm{~m}$. In those cases, the grid post was positioned north 
of the camera. The tripod was leveled with a bubble level. Focus was set to infinity and the F-stop usually at 2.8. Shutter speed varied from 1/125th at optimal light conditions, to $1 / 60$ th and $1 / 4$ th of a second). If speeds greater than $1 / 125^{\text {th }}$ were possible, the F-stop was increased. Two photos were taken for each of the grid points at camera exposures 0 and + respectively. The photos were oriented north by sighting across the middle of the fisheye lens using a white mark on the south side and a red high-output LED at the north end. The camera was oriented such that the magnetic north is located at the top of photographs. Pictures were taken during overcast skies to avoid direct sunlight that causes bright reflections on foliage, making them indistinguishable from the sky. Each photograph was logged in a notebook and any observations about the site, such as new gap formation, were recorded.

\section{PHOTOGRAPHIC ANALYSIS}

The photographic images were scanned using an Olympus slide scanner at $640 \mathrm{x}$ 400 pixels. Photos were saved in color BMP format and modified using Image Tool Software. The images were first converted to gray scale (256 scales, 8bpp) and then to binary (black and white pixels) using a manual threshold and comparing the result with the photographic image. The images were opened side by side and the threshold adjusted to optimize canopy openings and distinguishing leaves from sky while viewing the entire image. The threshold estimation was done independently two times to avoid bias and the binary image was saved to the average threshold. The images were changed to PCX format and analyzed for canopy and light parameters using WINPHOT (Ter Steege 1996). Using the program configuration for La Selva, which includes latitude, longitude 
among other geographical parameters, the program calculated LAI and Openness values, which were saved on an MS-Excel spreadsheet for the statistical analysis.

\section{DATA ANALYSIS}

When more than one photo per site was taken, the canopy openness and LAI values from the photos taken at optimum exposure ( 0 reading on the light meter) were used in the analysis. A small number of data points were missing in the analysis because of problems during film development or missing grid points. Because the sample design was based on repetitive sampling of the same points, Repeated Measures Analysis of Variance (RMANOVA) was used for all analysis within the PROC MIXED module of the SAS statistical software package (SAS 9.1.3, SAS Institute, Cary, NC). Three major analyses were performed. First, the effect of topography (flat vs. slope) and soil type (alluvial vs. residual) on the seasonal measurements of plot canopy openness and LAI values (static values) were tested separately for each season (wet and dry). Second, to test for changes from one sample period to the next, the difference in canopy openness and LAI (dynamic values) from the dry season to wet season within a year was compared using the RMANOVA. Finally, the plot canopy openness and LAI values were tested for seasonal differences (wet vs. dry) using the full data set. For all analyses, values were tested for normality and transformed when necessary and the residuals carefully inspected. Canopy openness was log-transformed for all analyses except for the dynamic comparison. 


\section{RESULTS}

\section{GENERAL PATTERNS}

For both the dry and wet seasons, the means of openness and LAI for the residual soil plots $\mathrm{L}$ and $\mathrm{P}$ were more similar to each other than to the alluvial plots $\mathrm{A}$ (Figure 2). The similarity of residual soil plots was particularly strong in the dry season. For all three plot types, strong year to year differences were apparent (Figure 2). For example, the canopy was more open in the A plots in 1999 and 2002, in the L plots in 1998 and 2001, and in the P plots in 2000, 2003 and 2004 (Figure 2). For the wet season, the canopy was the least open in the A plots from 1998 to 2004, and most open for the L plots in 1998, 2000, and 2003 and for the P plots in 1999, 2001, 2002, and 2004 (Figure 2). Furthermore, strong seasonality effects were apparent (Figure 3). For example, openness values (seen as mirror images of LAI) were higher during the dry season compared to the wet season on the A plots in 1998, 1999, and 2002, on the L plots in 1998 and 1999, and on the P plots on 1998, 1999, 2000, and 2003.

\section{TOPOGRAPHICAL AND SOIL EFFECTS}

\section{Static Comparisons}

Neither Openness nor LAI differed between slope conditions (flat versus slope) in either season (Table 1, Figure 4). The effect of soil types (alluvial versus residual) was also not significant (Table 1, Figure 5), though in the wet season $\mathrm{P}$ values were much lower than in the dry season. In terms of both Openness and LAI the slope $\mathrm{x}$ year interaction was not significant. However, for both openness and LAI the soil $\mathrm{x}$ year interaction was highly significant $(\mathrm{P}<0.0001)$ for the dry season but not for the wet 
season. This interaction indicates that temporal patterns of the soil types were different as can be seen in Figure 5. For the dry season the canopy was more open in the residual soils for years 1998, 2000, 2001, and 2003 but not for years 1999, 2002 and 2004.

\section{Dynamic Comparisons}

The changes in canopy openness and LAI from wet season to dry season over the period 1998-2004 were estimated by calculating the differences between wet and dry season values. Repeated measures ANOVA for change in openness and LAI did not differ between flat and slope conditions or between alluvial and residual soils. The effect of soil approached significance with $\mathrm{P}<0.1$. For openness there was a significant two-way interaction between soil and year, again showing an effect of soil type on the temporal pattern (Figure 6, Table 2).

\section{SEASONAL COMPARISONS}

Openness and LAI comparisons between the dry and wet seasons were close to significant $(\mathrm{P}=0.089$ for openness and $\mathrm{P}=0.063$ for LAI, Table 3 ). For both openness and LAI there were significant two-way interactions between soil and year and between season and year $(\mathrm{P}<0.001)$, and three-way interactions between season, soil, and year. Similarly, in terms of LAI, there was a significant two-way interaction between soil and year $(\mathrm{P}=0.0010)$ and between season and year $(\mathrm{P}<0.001)$, and a three-way interaction between season, soil, and year $(\mathrm{P}=0.0001$, Table 3$)$. 
INTERANNUAL VARIATION

Virtually all comparisons showed highly significant inter-annual variation for both openness and LAI, including static wet season only and dry season only comparison as well as the dynamic comparison (Figure 7, Tables 1-3). Peaks of openness were noticeable in the dry season of 1999 and both seasons of 2001. This variation was not directly attributable to simple climate variation. Plots of LAI with dry and wet season rainfall did not show significant relationships between LAI and rainfall (Figure 8). Likewise, no relationships were apparent between LAI and seasonal maximum and minimum temperatures (Figure 9).

\section{DISCUSSION}

The patterns seen in this data set are caused by a combination of seasonal changes in leaf area coverage, forest dynamics resulting from the gap formation and closure, and interannual variation in leaf area coverage due to variation in climatic factors. Consequently, interpretation of topographic and soil type effects was complicated by the interaction of these sources of variation, which may or may not be acting in concert. The forest dynamics include differences in canopy cover between the wet and sporadic dry seasons as well as differences due to temperature and precipitation variation among years, causing LAI and openness to vary inter-annually and intra-annually as well. In addition, different species respond to environmental stresses and opportunistic events (gap formation) that start new building phases in different manners creating the forest mosaic observed at La Selva. 


\section{TOPOGRAPHY}

I had hypothesized that topography would have strong effect on canopy openness and LAI and within-year change in these parameters. Instead, the effect of slope did not approach significance in any single factor or two factor analysis. This result was unexpected given the issues of topographic effects on wind, slope stability, forest structure, and soil moisture discussed previously. Given the similarity between the $\mathrm{L}$ and P plots, yet the differences from the A plots and the close temporal concordance among residual plots over time, the question as to whether the technique was sufficiently sensitive to detect differences in slope seems moot. I have to conclude that the absence of a topographic effect is real.

Why was there no effect of topography? The forest at La Selva and this data set has some characteristics that might overwhelm any expected slope effects. The La Selva forest is known for its dynamic nature with high gap formation rates (Denslow 1986). While down-slope water and nutrient movement leads to lower root biomass in lower slope, root biomass is similar to that of the ridgetop for much of the slope (Espeleta et al, unpublished data). The high rainfall at La Selva may overcome topographic soil moisture effects most of the time, but should increase landslip conditions. However, landslides at La Selva are rare. In fact, during this seven year study, there were no occurances of landslips in the study plots. In addition, the heavy epiphyte loads at La Selva may be a more important driver of tree and branch falls than wind or soil stability (Strong 1977). Damaging winds at La Selva are typically a result of downdrafts from convection storms and thus would not be strongly affected by topography. While the 
forest structure and species composition along slopes and plateaus tend to be different (Clark and Clark 2000), the forest structural differences may be counteracting.

Different species have different attributes such as LAI and how much they allocate to roots. They differ in their response to disturbance, water, temperature, nutrient and epiphyte load stresses. In different forests, species distribution may or may not be different at different topographical conditions. For instance, Kubota (2004) in a subtropical forest in Okinawa found species richness increased from the valley via slopes to the ridges, while Ashton (1995) found the understory survival was less in the ridge top than the valley and midslope sites. In a tropical montane forest in Borneo, Aiba (2004) found mean growth rates at $10-40 \mathrm{~cm}$ diameter and size distributions of species were not related to topographic associations. In a temperate mixed forest in Japan, (Nagamatsu et al 2003) found the upper hillslope area had higher tree densities and larger basal areas than the lower hillslope. However, the authors do not rule out the possibility of this effect being because of the longer lifespans of trees in the upper hillslopes. In addition, one important way topography affects tree distributions is through soil water contents. Plateaus (L plots) are generally drier compared to Alluvial plots, but in fact $4 \mathrm{~m}$ deep soil pits were constructed at La Selva and during heavy rain higher water tables accumulate in the L plots making their water content similar to the A plots. The plateau and slope plots may not be that different in terms of water content compared to the alluvial plots. Basnet (1992) in two adjacent watersheds of the Luquillo Experimental forest in Puerto Rico, found ridgetops and slopes had a more similar tree distribution than valleys. The species similarities and their interaction with the microenvironment may have masked any differences between the slope and flat conditions. 


\section{SOIL EFFECTS}

The effects of soil type approached significance as single factor and the interaction between soil and year was significant in several analyses. These results indicate that as hypothesized, soil type influences estimates of canopy coverage; however on a temporal basis. The basis for soil effects can arise from several factors: 1) differences in water holding capacity of soil (higher for alluvial, E. Veldkamp, unpublished data), 2) differences in soil moisture (higher in alluvial, D. Clark et al, unpublished data), 3) differences in root biomass (higher on low nutrient soils, J. Espeleta et al unpublished data), and 4) differences in species composition. Interestingly, aboveground biomass is similar among the plots in different soil types (Clark and Clark, 2000).

The significant soil $\mathrm{x}$ year interactions indicate that the soil type response of canopy coverage parameters differed with time. This study included two ENSO periods 1997-1998, 2002-2003, and one La Niña period (1998-1999). ENSOs at La Selva are associated with drier dry seasons and warmer nighttime temperatures which is associated with increased tree mortality (Clark et al 2003, unpublished data). A key question is which of the properties mentioned above influences canopy cover response to these events.

\section{SEASONAL EFFECTS}

Differences in openness and LAI between the dry and wet seasons were close to significance and the season by year interactions were highly significant. During the dry season canopies open as trees shed their leaves, and during the wet season the canopy closes as dry season deciduous and leaf exchanging species releaf. However, this 
expected seasonal pattern was not observed in all years on all plots. In fact variation in the strength of the dry season interacted with inter-annual variation in coverage to make a more complex pattern in which some years, the dry season had higher coverage than the wet season (Figure 7). On the A, L, and P plots, the canopy closed (lower openness and higher LAI) from the dry season to the wet season and opened from wet season to dry season from dry season 1998 to wet season 2000. However, in all plots the canopy closed from wet season 2000 to dry season 2001 and opened from dry to wet season 2001. From 2002 wet season to wet season 2004 the canopy closed for all plots. These results could have occurred for several reasons. Different species have different attributes such as differences in LAI, leaf phenology, and in how much they allocate to roots as well as different resistance to disturbances and environmental stresses such as water, temperature, nutrients and epiphyte loads, and these factors are different among years. In addition, the seasonality effects may have been masked during certain years due to differences in the strength and length of the dry season. As seen in previous studies, length of the dry period may have a strong effect on leaf dynamics, plant growth and survival in tropical rain forests (Poorter \& Hayashida-Oliver 2000, Chazdon 2005).

For instance, during wet dry seasons, deciduous species are leafless for less time and evergreen species retain leaves longer causing the LAI to be different from the expected seasonal pattern.

\section{INTERANNUAL VARIATION}

I found highly significant interannual variation in all analyses that was concordant on all plot types (Figure 7, Tables 1-3). As mentioned above, this data set spanned two ENSO 
and one La Niña events, which had significant effects on tree growth and mortality (Clark and Clark 1994, Clark et al 2003, Clark et al unpublished data. They found higher mortality and substantially lower growth in ENSO years. The peak in openness in 1999 followed an unprecedented high mortality rate in 1998. Clark et al (unpublished data) and Espeleta et al (unpublished data), found similar large inter-annual variation of root biomass in the same plots over the same period. In addition, during ENSO events (19981999 and 2002-2003) when it is hotter and drier in the dry season, trees usually drop leaves prematurely contributing rich litter into the soil. However, with the 1998 ENSO wet season and the 1999 La Niña (Figure 8) when conditions were wetter, this flush of nutrients may have been leached away (Wood et al 2005). Consequently, at the La Selva forest, leaf litter nutrient concentration varies inter-annually (Wood et al 2005), likely as a result of the interaction between the timing and intensity of leaf fall and the timing and intensity of subsequent rainfall. This variation in available nutrients undoubtedly affects leaf area development in following years (Lodge \& McDowell 1994) and may in part explain why a peak in openness was observed in 1999 following the 1998 ENSO event. Events such as ENSO and La Niña clearly affect soil properties such as soil moisture and soil nutrients and these events vary inter-annually. Inter-annual variation is a function of both seasonal leaf dynamics and leaf area differences from climate. In drier years trees shed their leaves more than in wetter years so LAI will be lower for drier years. Other factors that can vary among years also may affect LAI. These include stand age, radiation input and interception, development of current year foliage and loss of previous year's foliage. Furthermore, stresses such as reduced nutrient supply, drought or temperature stress may reduce canopy LAI sufficiently to stimulate branch retention and 
leaf growth in the lower crown (Vose and Swank 1990, Asner et al 2003). In addition, trees are constantly falling and being replaced by new species creating a mosaic of ages (building phase, mature, old growth) as a result of the gap regeneration cycle. However, Souza \& Martins 2005) argue that the gap dynamic regime is less important for changes in openness than the effect of the dynamics of understory shrubs, saplings, subcanopy and canopy growth.

\section{LAI VERSUS OPENNESS}

For the most part there was a good correspondence between openness and LAI in the analyses. However, there were some instances where openness and LAI significances were different (Table 2). For example, for the soil factor in canopy dynamics LAI measurements were almost significant while canopy openness measurements yielded no significance. Differences may have occurred for several reasons. LAI and openness in this data set were curvilinearly related (Figure 10). While LAI is the more meaningful of the two variables for physiological and ecosystem studies, it is an inverted measurement of openness. In contrast openness is a measure of the space that leaves are not occupying. Openness spans a wide range of values and is less likely to saturate at high cover values than LAI. At LAI of $>6$ the photographic method of determining LAI has serious limitations. Furthermore, photos taken beneath large gaps violate the assumption of random distribution of leaves for determination of LAI. 


\section{CONCLUSIONS}

The patterns observed in this study are a result of a combination of seasonal changes in leaf area coverage, forest dynamics resulting from the gap formation and closure, and inter and intra-annual variation in leaf area coverage due to variation in climatic factors. As hypothesized, I found significant soil type influences on estimates of canopy cover, but in the form of soil type* year interactions. The direct effect of soil type was not large enough to be significant, but the interactive effects of soil type on temporal patterns were very strong. Perhaps most surprising was what was not found; a significant effect of slope on any estimator of canopy coverage in any analysis. Seasonal differences in cover parameters were expected due to changes in leaf area cover between wet and dry seasons, but interestingly, the effect was not one of consistently low coverage in the dry season. Instead, variation in the strength of the dry season interacted with inter-annual variation in coverage to make a more complex pattern in which some years, the dry season had higher coverage than the wet season. Also unexpected was the magnitude of the year-toyear differences in canopy cover parameters. This is the first long-term study to document substantial inter-annual variation in canopy cover for a tropical wet forest. This variation in canopy cover was apparent as a result of strong climatic differences driving both individual tree leaf area coverage and forest dynamics (gap formation and closure). These new insights add a new dimension to our understanding of the complex interactions within canopy of one of the most eutrophic and clearly most dynamic tropical forests. 
Table 1. Results from Repeated Measures ANOVA for annual (static) dry and wet season measurements of canopy openness and leaf area index (LAI).

\begin{tabular}{lccccc}
\hline Effect & DF & F & $\begin{array}{c}\text { Canopy openness } \\
\text { P }\end{array}$ & \multicolumn{2}{c}{$\begin{array}{c}\text { Leaf Area Index (LAI) } \\
\text { P }\end{array}$} \\
\hline Slope & 15 & 0.56 & 0.4660 & 0.00 & 0.9551 \\
Soil & 15 & 0.01 & 0.9266 & 0.22 & 0.6437 \\
Year & 710 & 66.32 & $<0.0001$ & 64.46 & $<0.0001$ \\
Soil*Year & 710 & 5.66 & $<0.0001$ & 7.49 & $<0.0001$ \\
Slope*Year & 710 & 0.58 & 0.75030 & 0.71 & 0.6418 \\
& & & & WET SEASON & \\
Slope & 15 & 0.45 & 0.5102 & 0.00 & 0.9507 \\
Soil & 15 & 0.90 & 0.3566 & 2.62 & 0.1262 \\
Year & 709 & 80.16 & $<.0001$ & 78.37 & $<.0001$ \\
Soil*Year & 709 & 0.68 & 0.6671 & 0.42 & 0.8675 \\
Slope*Year & 709 & 0.59 & 0.7355 & 0.91 & 0.4869 \\
\hline
\end{tabular}


Table 2. Results from Repeated Measures ANOVA for differences (dynamics) from dry to wet season measurements of canopy openness and leaf area index (LAI).

\begin{tabular}{lccccc}
\hline Effect & DF & F & Canopy openness & \multicolumn{2}{c}{ Leaf Area Index (LAI) } \\
& & & & \multicolumn{3}{c}{ Dry to Wet Season } \\
& & & & 0.58 & 0.4597 \\
Slope & 15 & 0.07 & 0.8000 & 0.58 & \\
Soil & 15 & 1.50 & 0.2396 & 3.12 & 0.0977 \\
Year & 699 & 89.57 & $<0.0001$ & 68.07 & $<0.0001$ \\
Soil * Year & 699 & 7.02 & $<0.0001$ & 4.09 & 0.0005 \\
Slope*Year & 699 & 1.32 & 0.2449 & 0.73 & 0.6223 \\
\hline
\end{tabular}


Table 3. Results from Repeated Measures ANOVA comparing wet versus dry season measurements of canopy openness and leaf area index (LAI).

\begin{tabular}{llllll}
\hline & \multicolumn{3}{c}{ Canopy openness } & \multicolumn{2}{l}{ Leaf Area Index (LAI) } \\
\hline Effect & DF & F & P & F & P \\
\hline Season & 30 & 3.09 & 0.0889 & 3.72 & 0.0632 \\
Slope & 30 & 1.01 & 0.3221 & 0.01 & 0.9351 \\
Soil & 30 & 0.53 & 0.4728 & 2.14 & 0.1541 \\
Year & 1419 & 43.70 & $<0.0001$ & 44.24 & $<0.0001$ \\
Soil * Year & 1419 & 3.68 & 0.0013 & 3.77 & 0.0010 \\
Slope*Year & 1419 & 0.70 & 0.6511 & 0.74 & 0.6212 \\
Season * Year & 1419 & 65.02 & $<0.0001$ & 65.95 & $<0.0001$ \\
Season*Soil*Year & 1419 & 2.73 & 0.0081 & 3.82 & 0.0004 \\
Season*Slope*Year & 1419 & 0.41 & 0.8992 & 0.76 & 0.6202 \\
\hline
\end{tabular}




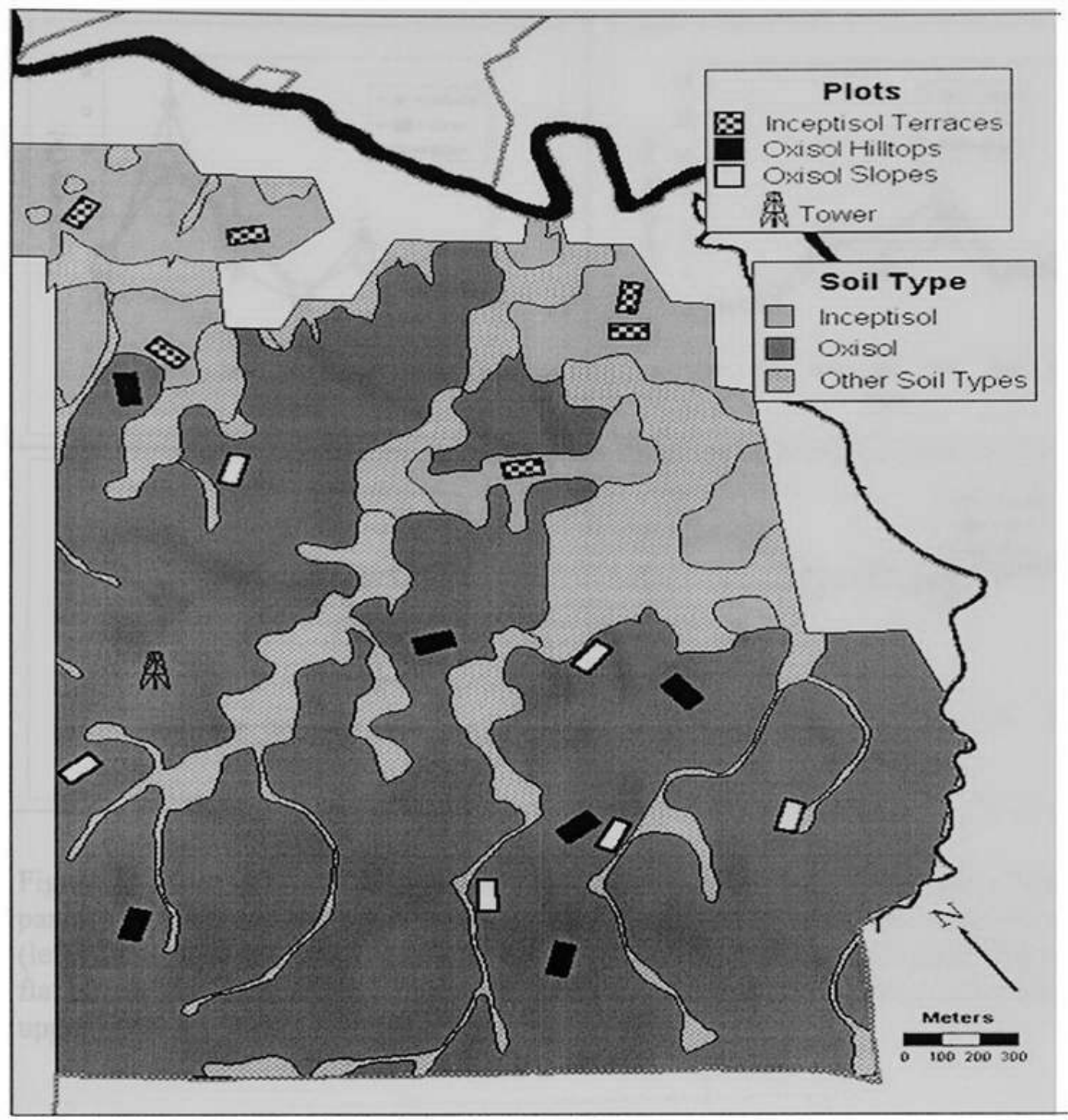

Figure 1. Location of study plots within soil types at La Selva, Costa Rica. Inceptisol terraces are alluvial soils and Oxisols (in some treatments considered Ultisols) are residual soils. 


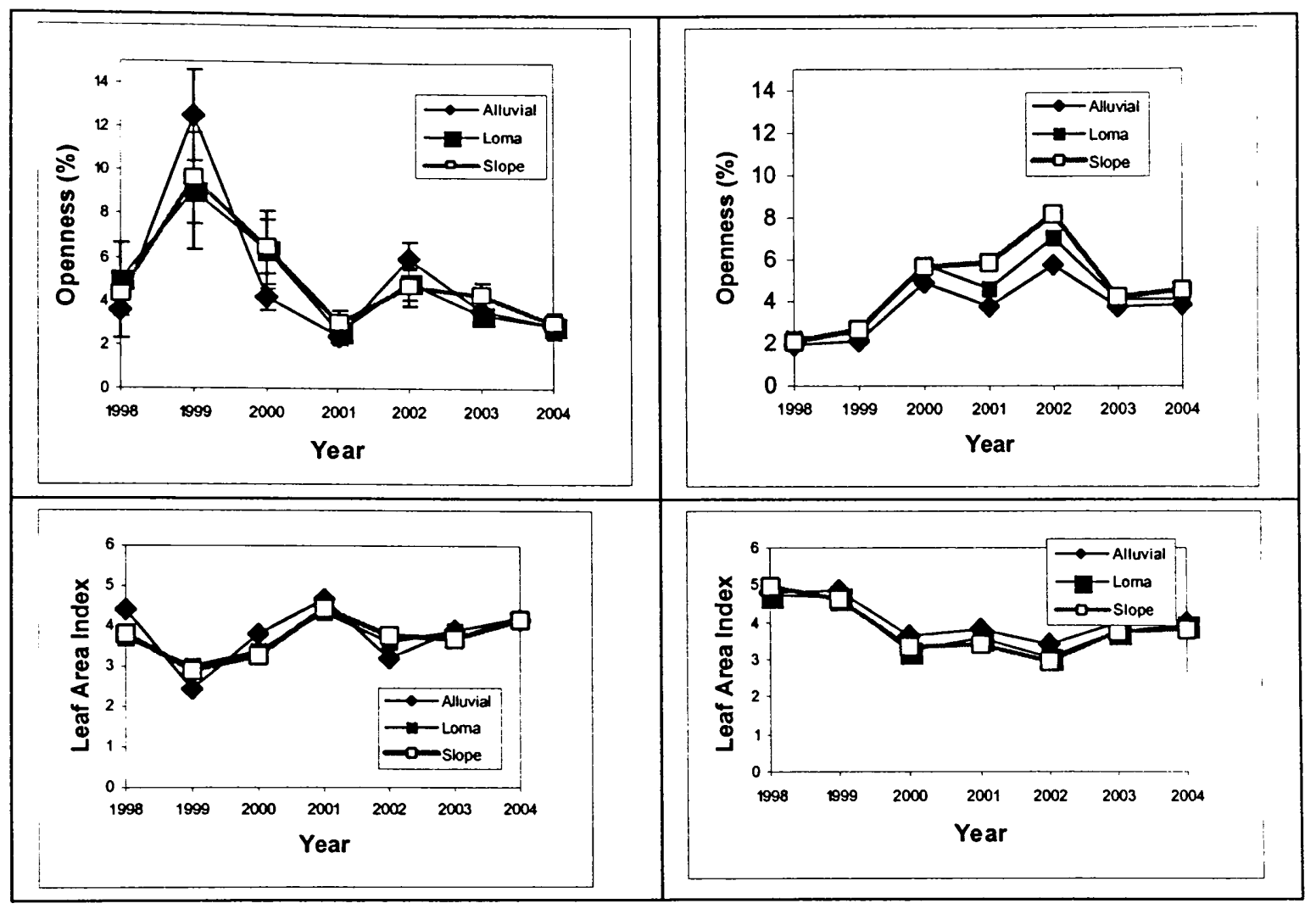

Figure 2. Mean values of canopy openness (upper panels) and leaf area index (lower panels) for the three plot types studied in old-growth forest in Costa Rica for dry season (left panels) and wet season (right panels). Alluvial are flat inceptisol plots, Loma are flat ultisol plots, and slope are sloped ultisol plots. Representative error bars shown in upper panel are standard errors of the mean $(n=6)$. 


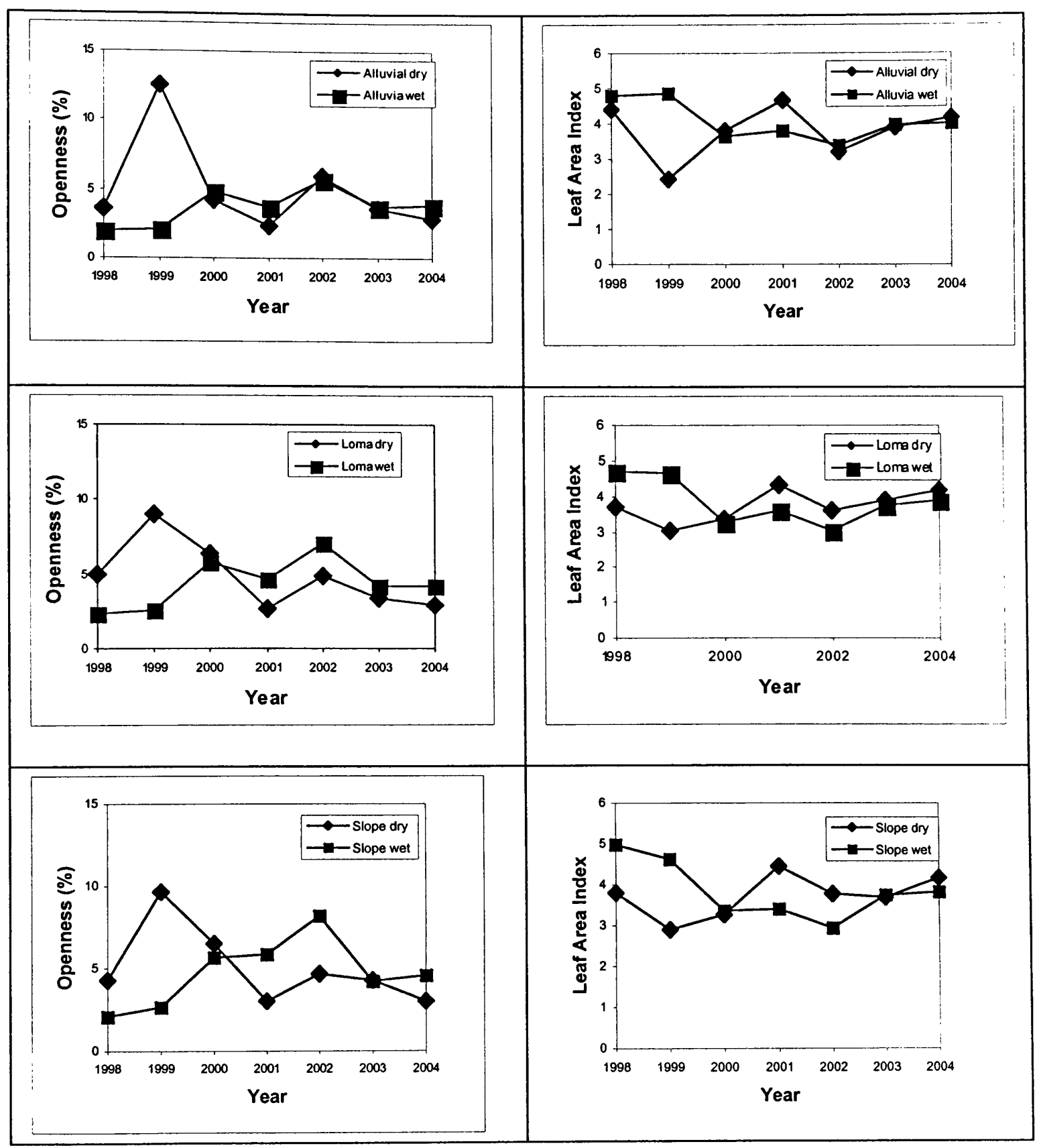

Figure 3. Canopy openness (left panels) and leaf area index (right panels) for wet and dry season for the three plot types described in Figure 2. 


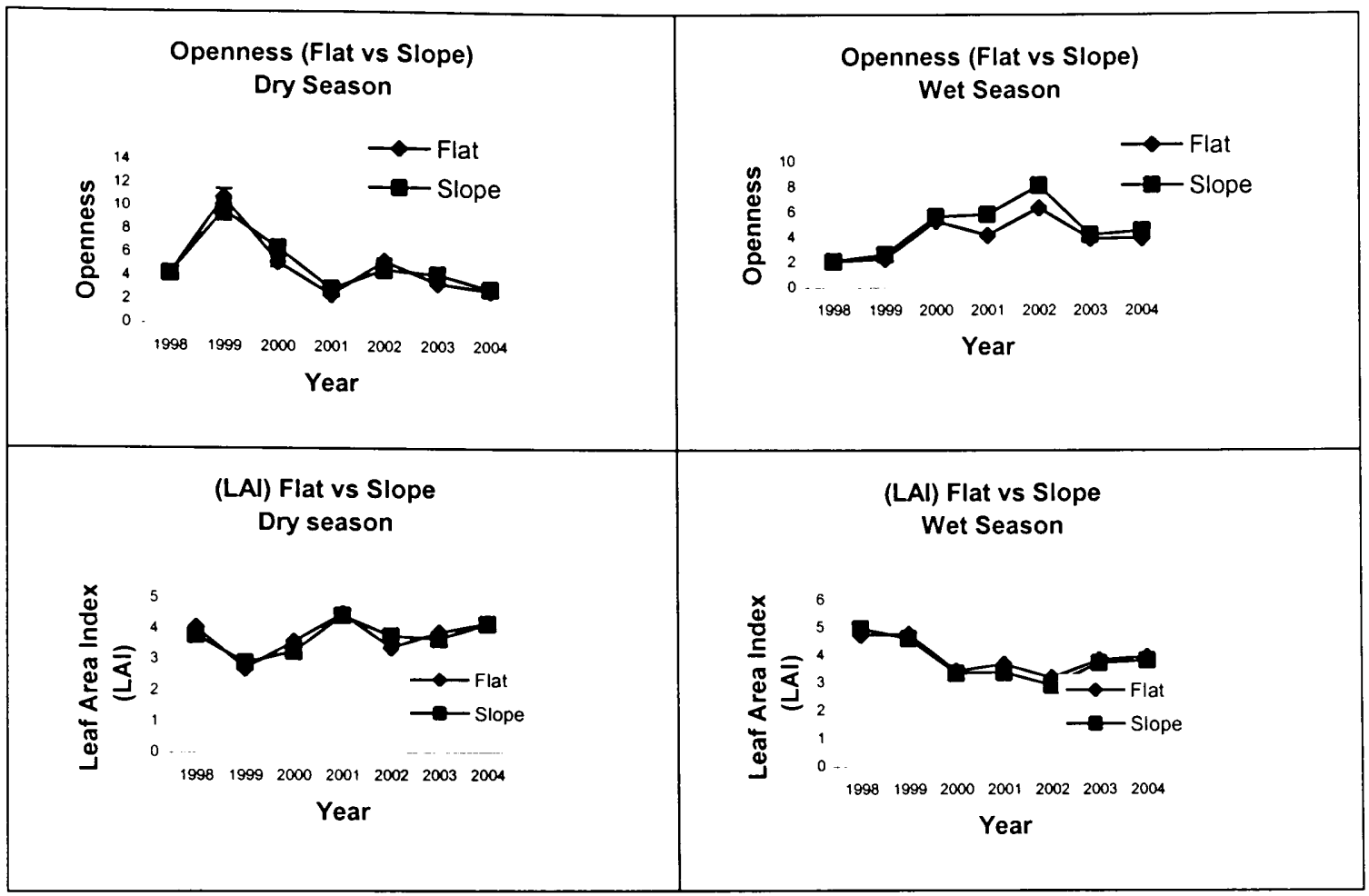

Figure 4. Mean values of canopy openness (upper panels) and leaf area index (lower panels) for the flat vs slope relationship for dry season (left panels) and wet season (right panels). 


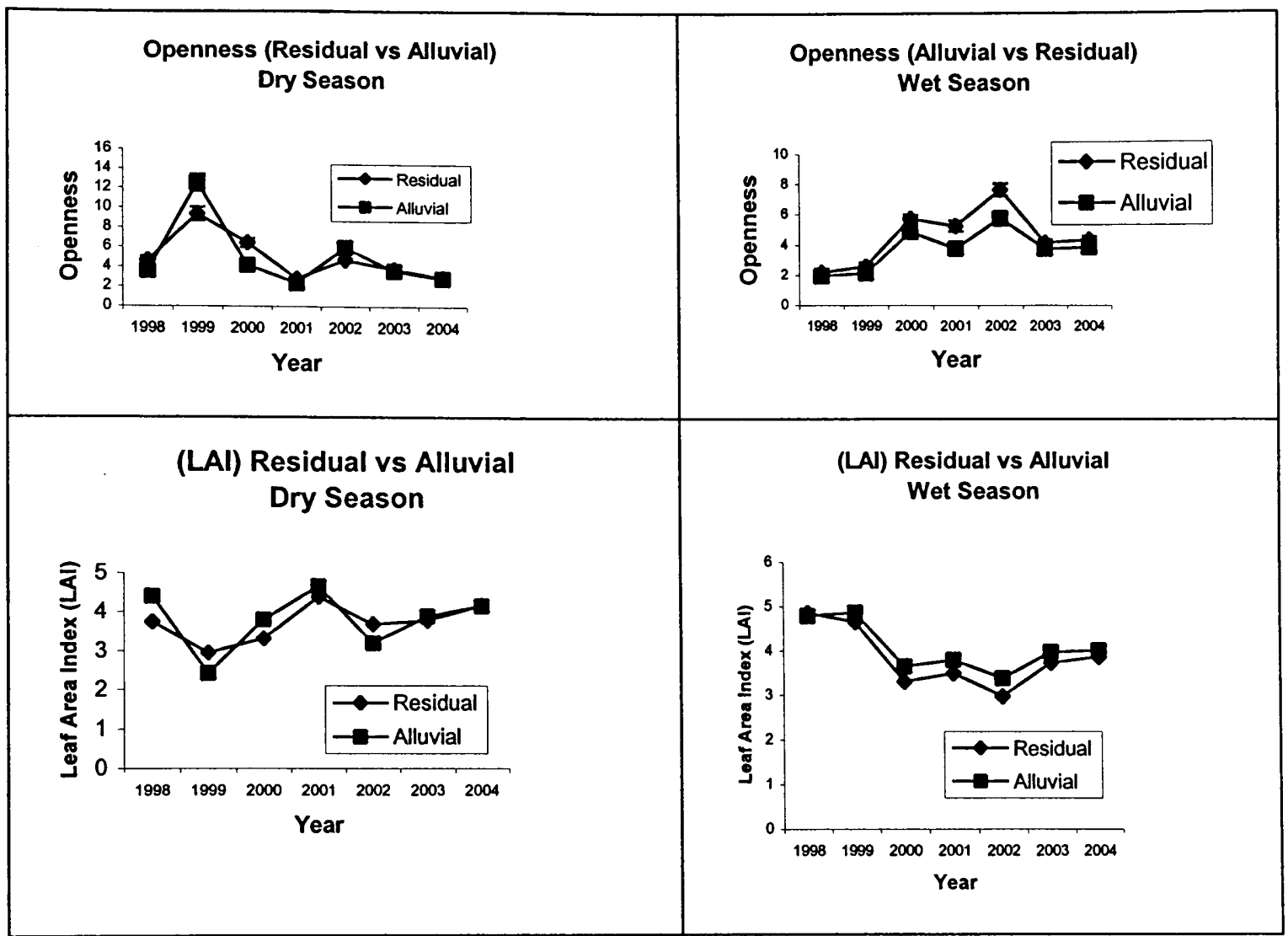

Figure 5. Mean values of canopy openness (upper panels) and leaf area index (lower panels) for the alluvial vs residual relationship for dry season (left panels) and wet season (right panels). 


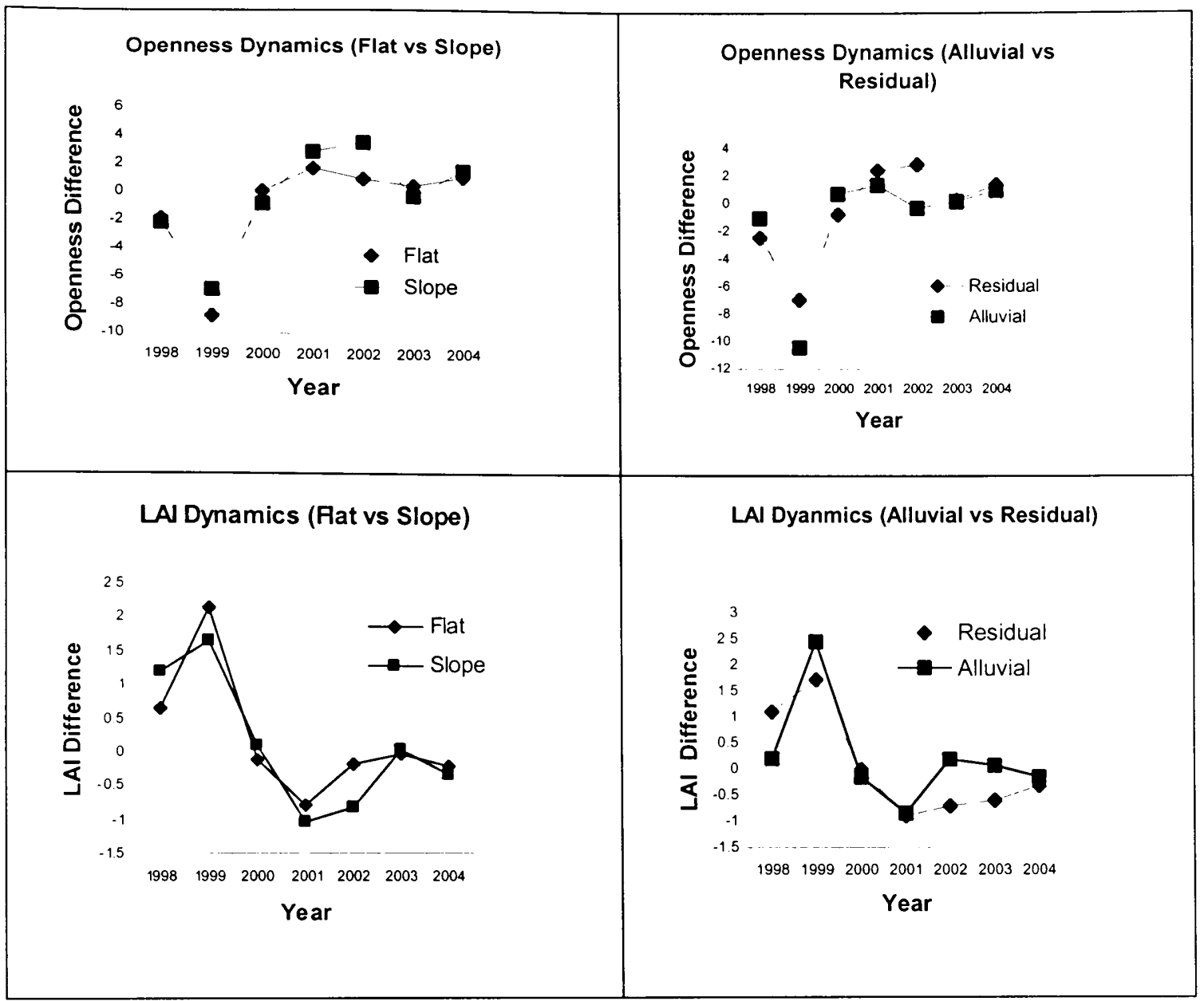

Figure 6. Mean values of canopy openness (upper panels) and leaf area index (lower panels) for the flat vs slope relationship for dry season (left panels) and the alluvial vs residual relationship (right panels). 


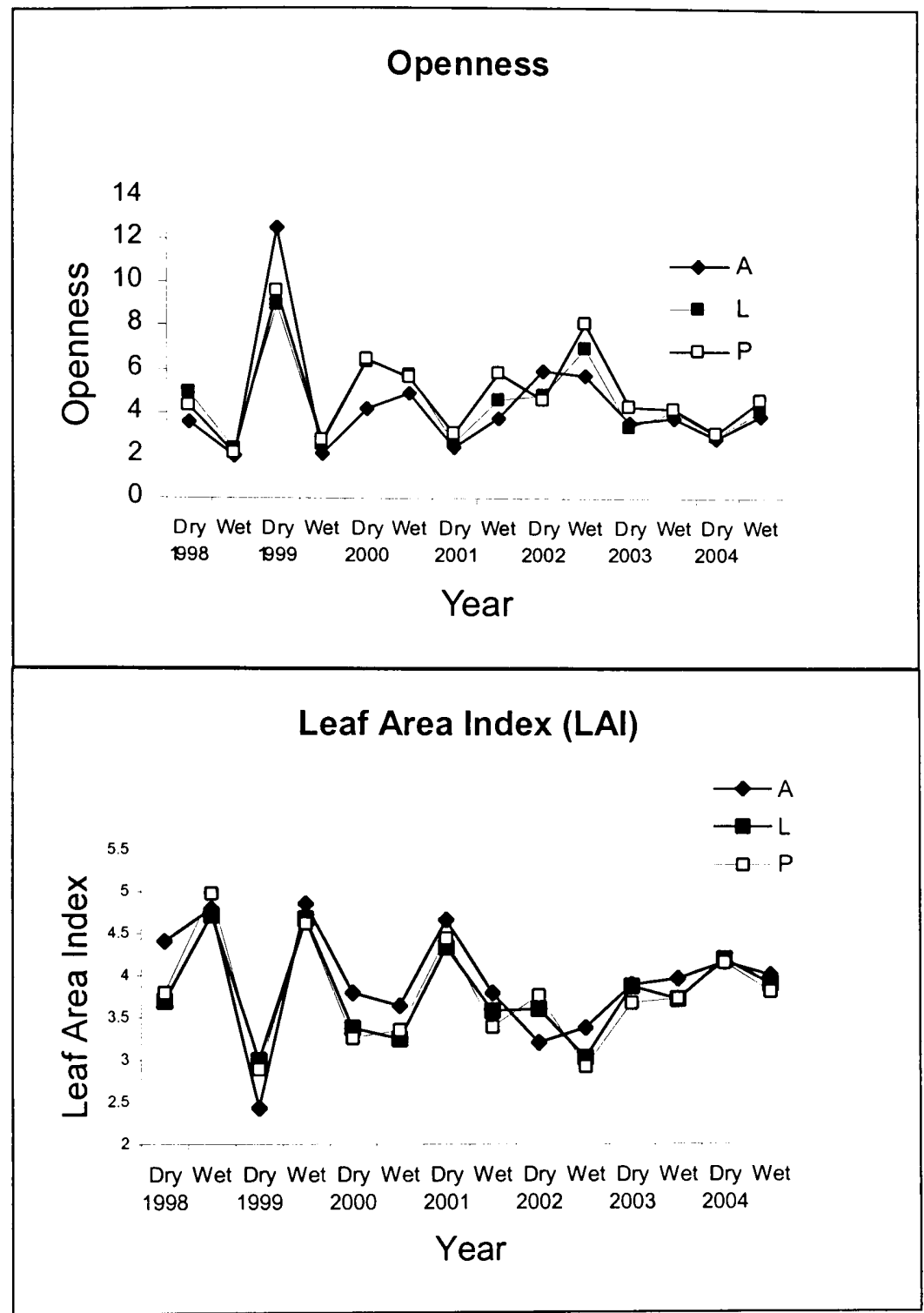

Figure 7. Patterns of intra-annual variation in openness and LAI 


\section{Leaf Area Index and Annual Rainfall}

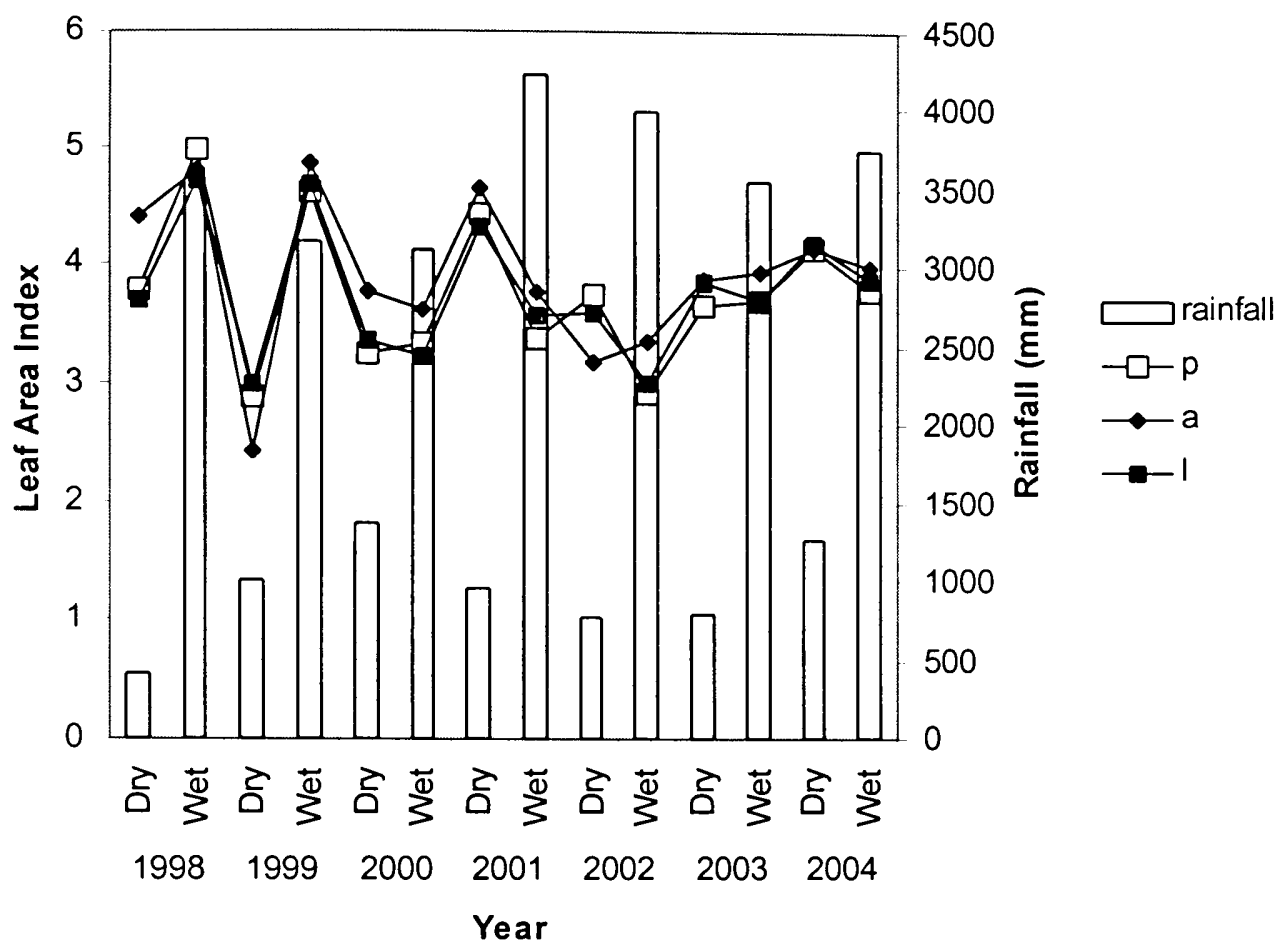

Figure 8. Mean seasonal LAI and rainfall in dry and wet seasons from 1998-2004 


\section{Leaf Area Index and Annual Temperature}
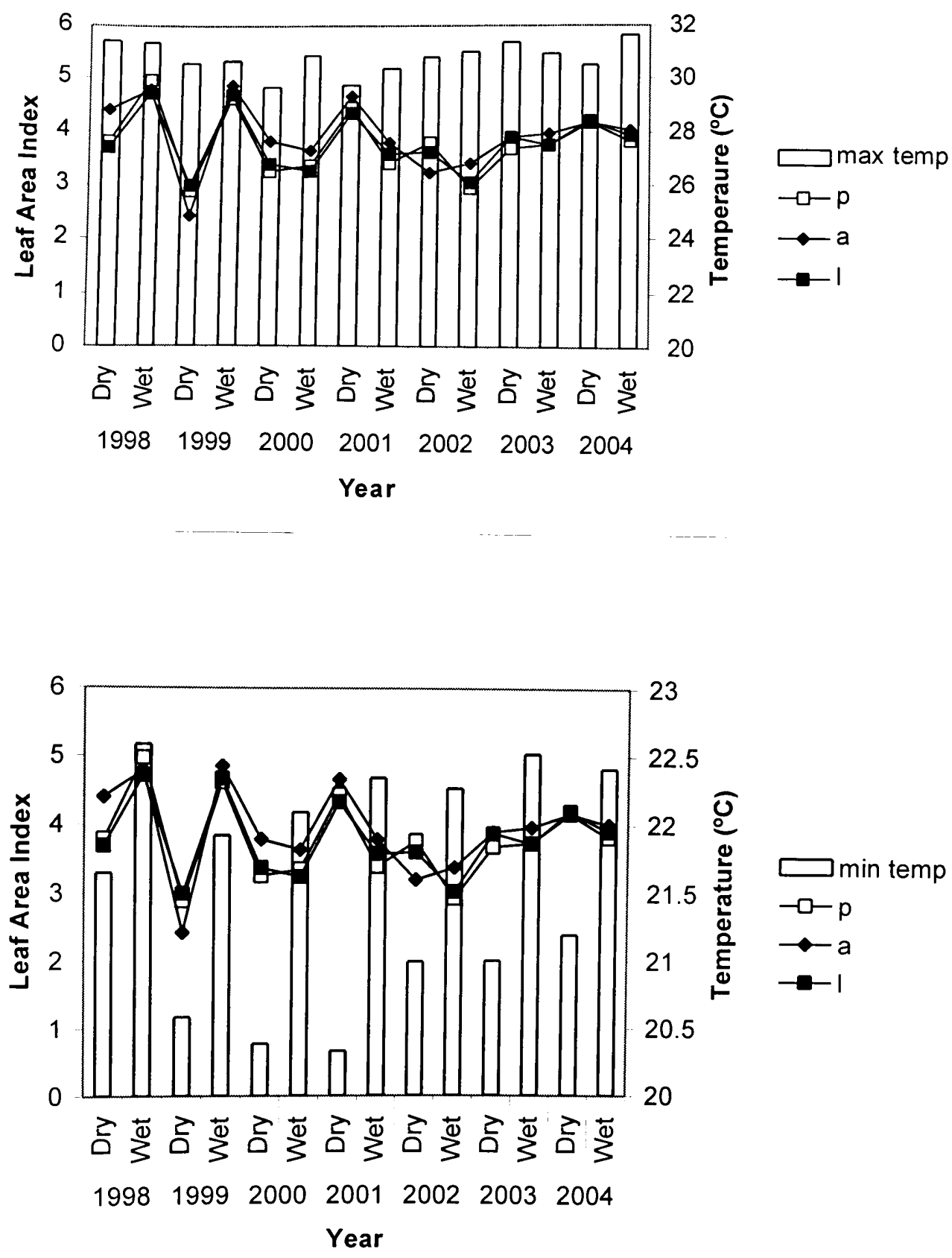

Figure 9. Mean seasonal LAI and maximum (upper) and minimum (lower) temperature in dry and wet seasons from 1998-2004 


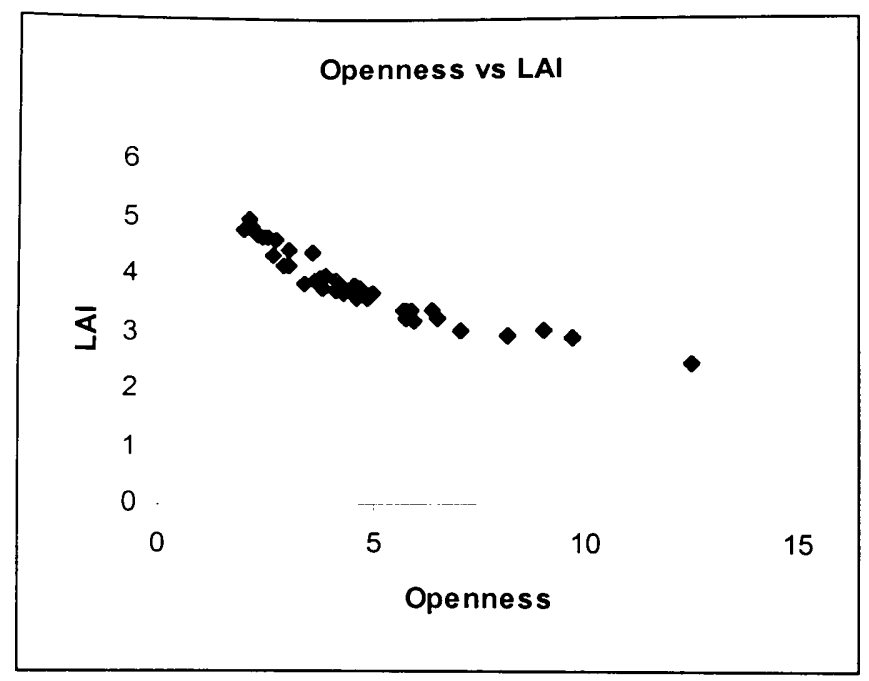

Figure 10. Relationship between openness and LAI. 


\section{LITERATURE CITED}

Aiba S, Kitayama K, Takyu M (2004) Habitat associations with topography and canopy structure of tree species in a tropical montane forest on Mount Kinabalu, Borneo. Plant Ecology 174:147-161

Anderson AR (1964) Observations on climatic damage in peat swamp forest in Sarawak. Commonwealth Forestry Review 43:145-158

Anderson JM, Swift MJ (1983) Decomposition in tropical forests. In: Sutton SL, Whitmore TC, Chadwick AC (eds) The Tropical Rain Forest. Blackwell Scientific, Oxford, pp 287-309

Ashton, PMS, Gunatilleke, CVS, Gunatilleke, IAUN (1995) Seedling survival and growth of four Shorea species in a Sri Lankan rainforest. Journal of Tropical Ecology 11:263-279

Asner G, Scurlock J, Hicke J (2003) Global synthesis of leaf area index observations: implications for ecological and remote sensing studies. Global Ecology and Biogeography 12:191-205

Aubreville A (1938) La foret coloniale: les forets d'Afrique occidental francaise. Annales Academie des Sciences Colonales 9:1-245

Basnet K (1992) Effect of topography on the pattern of trees in Tabonuco (Dacryodes excelsa) dominated rain forest of Puerto Rico. Biotropica 24:31-42

Bazzaz FA (1983) Characteristics of population in relation to disturbance in natural and man-modified ecosystems. In: Mooney HA, Gordon M (eds) Disturbance and Ecosystems: Components of Response, Springer-Verlag, New York, NY, pp 259275

Becker P, Rabenold PE, Idol JR, Smith AP (1988) Water potential gradients for gaps and slopes in a Panamanian tropical moist forest's dry season. Journal of Tropical Ecology 4:173-184

Bonhomme R, Chartier P (1972) The interpretation and automatic measurement of hemispherical photographs to obtain sunlit foliage area and gap frequency. Israel Journal of Agricultural Research 22:53-61

Bose ER, Foster DR, Fluet M (1994) Hurricane impacts to tropical and temperate forest landscapes. Ecological Monographs 64:369-400 
Brokaw N (1989) Species composition in gaps and structure of a tropical forest. Ecology 70:538-541

Brokaw N, Busing R (2000) Niche versus chance and tree diversity in forest gaps. Trends in Ecology and Evolution 15:183-188

Brokaw NVL (1982) The definition of treefall gap and its effect on measures of forest dynamics. Biotropica 14:158-160

Brokaw NVL (1985) Treefalls, regrowth, and community structure in tropical forests. In: Pickett STA, White PS (eds) The Ecology of Natural Disturbance and Patch Dynamics. Academic Press Inc, San Diego, CA, pp 53-69

Bugmann H, Reynolds J, Pitelka L (2001) How much physiology is needed in forest gap models for simulating long-term vegetation response to global change? Climatic Change 51:249-250

Busing R (1996) Estimation of tree replacement patterns in an Appalachian Picea-Abies forest. Journal of Vegetation Science 7:685-694

Canham C, Marks P (1985) The response of woody plants to disturbance: Patterns of establishment and growth. In: Pickett ST, White PS (eds) The Ecology of Natural Disturbance and Patch Dynamics. Academic Press Inc, San Diego, CA, pp 197216

Canham C, Denslow JS, Platt W, Runkle J, Spies TA, White PS (1990) Light regimes beneath closed canopies and tree-fall gaps in temperate and tropical forests. Canadian Journal of Forest Research 20:620-631

Chazdon R, Fetcher N (1984) Photosynthetic light environments in a lowland tropical rain forest in Costa Rica. Journal of Ecology 72:553-564

Chazdon R, Pearcy R (1991) The importance of sunflecks fro forest understory plants. Bioscience 41:760-766

Chazdon R, Field C (1987) Photographic estimation of photosynthetically active radiation: evaluation of a computerized technique. Oecologia 3:525-532

Chazdon R, Brenes A, Alvarado B (2005) Effects of climate and stand age on annual tree dynamics in tropical second-growth rain forest. Ecology 86:1808-1815

Chen J, Cihlar J (1995) Plant canopy gap-size analysis theory for improving optical measurements of leaf-area index. Applied Optics 34:6211-6222 
Chen J, Rich P, Gower S (1997) Leaf area index of boreal forests: Theory, techniques, and measurements. Journal of Geophysical Research 102:29429-29443

Clark D, Clark D (1990) Distribution and effects on tree growth of lianas and woody hemiepiphytes in a Costa Rican tropical wet forest. Journal of Tropical Ecology 6:321-331

Clark D, Clark D (1994) Climate-induced annual variation in canopy growth in a Costa Rican tropical rain forest. Journal of Ecology 82:865-872

Clark D, Clark D, Read J (1998) Edaphic variation and the mesoscale distribution of tree species in a neotropical rain forest. Journal of Ecology 86:110-112

Clark D, Clark D (2000) Landscape-variation in forest structure and biomass in a tropical rain forest. Forest Ecology and Management 137:185-198

Clark D, Clark D, Brown S, Oberbauer S, Veldkamp E (2002) Stocks and flows of coarse woody debris across a tropical rain forest nutrient and topography. Forest Ecology and Management 164:237-248

Clark D, Castro C, Alvarado L, Read J (2004) Quantifying mortality of tropical rain forest trees using high-spatial-resolution satellite data. Ecology Letters 7:52-59

Comeau P, Gendron F, Letchford T (1998) A comparison of several methods for estimating light under a paper birch mixed-wood stand. Canadian Journal of Forest Research 28:1843-1850

Connell J, Lowman M (1989) Low-diversity tropical rain forests, some possible mechanisms for their existence. American Naturalist 134:88-119

Deblonde G, Penner M, Royer A (1994) Measuring leaf-area index with the LI-COR LAI-2000 in pine stands. Ecology 75:1507-1511

Delucia E, Maherali H, Carey E (2000) Climate-driven changes in biomass allocation in pines. Global Change Biology 6:587-593

Denslow J, Ellison A, Sanford R (1998) Treefall gap size effects on above- and belowground processes in a tropical wet forest. Journal of Ecology 86:597-609

Denslow JS (1986) Tropical rain forest gaps and tree species diversity. Annual. Review of Ecology and Systematics 18:431-451

Denslow JS, Schultz JC, Vitusek PM, Strain BR (1990) Growth response of tropical shrubs to treefall gap environments. Ecology 71:165-179 
Enoki T, Abe A (2004) Sapling distribution in relation to topography and canopy openness in an evergreen broad-leaved forest. Plant Ecology 173:283-291

Fassnacht K, Gower S, Norman J, McMurtrie R (1994) A comparison of optical and direct methods for estimating foliage surface area index in forests. Agricultural and Forest Meteorology 71:183-207

Foster DR, Knight DH, Franklin JF (1998) Landscape patterns and legacies resulting from large, infrequent disturbances. Ecosystems 1:497-510

Gale N, Barfod AS (1999) Canopy tree mode of death in a western Ecuadorian rain forest. Journal of Tropical Ecology 15:415-436

Gale N, Hall P (2001) Factors determining the modes of tree death in three Bornean rain forests. Journal of Vegetation Science 12:337-346

Garwood NC, Janos DP, Brokaw NVL (1979) Earthquake-caused landslides: a major disturbance to tropical forests. Science 205:997-999

Gessler P, Chadwick O, Chamran F, Althouse L, Holmes K (2000) Modeling soillandscape and ecosystem properties using terrain attributes. Soil Science Society of America Journal 64:2046-2056

Gower S, Kucharik C, Norman J (1999) Direct and indirect estimation of leaf area index, fPAR and net primary production of terrestrial ecosystems. Remote Sensing of Environment 70:29-51

Grubb PJ (1977) The maintenance of species-richness in plant communities: the importance of the regeneration niche. Biol. Review. 52:107-145

Hartshorn GS (1980) Neotropical forest dynamics. Biotropica 12:23-30

Holdridge L (1967) Life zone ecology. Tropical Science Center, San Jose, Costa Rica

Horvitz C, Schemske D (1986) Seed dispersal of a neotropical myrmecochore variation in removal rates and dispersal distance. Biotropica 18:319-323

Hubbel SP, Foster RB, O'Brien ST, Harms KE, Condit R, Wechsler B, Wright SJ, Loo de Lao S (1999) Light-gap disturbances, recruitment limitation, and tree diversity in a neotropical forest. Science 283:554-557

Hubbel SP, Foster RB (1986) Canopy gaps and the dynamics of a neotropical forest. In: Crawley MJ (ed) Plant Ecology. Blackwell, Oxford, pp 77-96 
Hutchinson B, Matt D (1977) The distribution of solar radiation with a deciduous forest. Ecological Monographs 16:185-207

Imbert D, Rousteau A, Labbe P (1998) Hurricanes and biological diversity in tropical forests - The case of Guadeloupe. Acta Oecologica-International Journal of Ecology 19:251-262

Jans L, Poorter L, Vanrompaey RSAR, Bongers F (1993) Gaps and Forest Zones in tropical moist frorest in Ivory-Coast. Biotropica 25:258-269

Kapos V, Pallant E, Bien A, Freskos S (1990) Gap frequencies in lowland rainforest sites on contrasting soils in Amazonian Ecuador. Biotropica 22:218-225

Kimball J, Thornton P, White M (1997) Simulating forest productivity and surfaceatmosphere carbon exchange in the BOREAS study region. Tree Physiology 17:589-599

Kobe R, Pacala S, Silander J, Canham C (1995) Juvenile tree survivorship as a component of shade tolerance. Ecological Applications 5:517-532

Kobe R (1996) Intraspecific variation in sapling mortality and growth predicts geographic variation in forest composition. Ecological Monographs 66:181-201

Kobe R, Coates K (1997) Models of sapling mortality as a function of growth to characterize interspecific variation in shade tolerance of eight tree species of northwestern British Columbia. Canadian Journal of Forest Research 27:227-236

Krasny M, Whitmore M (1992) Gradual and sudden forest canopy gaps in Allegheny northern hardwood forests. Canadian Journal of Forest Research 22:139-143

Kubo T, Iwasa Y, Furumoto N (1996) Forest spatial dynamics with gap expansion: total gap area and gap size distribution. Journal of Theoretical Biology 180:229-246

Kubota Y, Murata H, Kikuzawa K (2004) Effects of topographic heterogeneity on tree species richness and stand dynamics in a subtropical forest in Okinawa Island, southern Japan. Journal of Ecology 92:230-240

Kucharik C, Norman J, Murdock L (1997) Characterizing canopy nonrandomness with a multiband vegetation imager (MVI). Journal of Geophysical Research 102:2945529473

Laurance WF, Ferreira LV, Rankin De Merona JM, Laurance SG (1998) Rain forest fragmentation and the dynamics of Amazonian tree communities. Ecology 79:2032-2040 
Lawton RO, Putz FE (1988) Natural disturbance and gap-phase regeneration in a windexposed tropical cloud forest. Ecology 69:764-777

Lieberman D, Lieberman M, Peralta R, Hartshorn GS (1985) Mortality patterns and stand turnover rates in a wet tropical forest in Costa Rica. Journal of Tropical Ecology 1:98-109

Lieberman M, Lieberman D, Peralta R, Hartshorn GS (1994) Canopy closure and the distribution of tropical forest tree species at La Selva, Costa Rica. Journal of Tropical Ecology 11:161-178

Lodge DJ, McDowell WH (1994) The importance of nutrient pulses in tropical forests. Trends in Ecology and Evolution 9:384-387

Magnusson WE, Lima AP, deLima O (1996) Group lightning mortality of trees in a Neotropical forest. Journal of Tropical Ecology 12:899-903

Marquis R, Young H, Braker EH (1986) The influence of understory vegetation cover on germination and seedling establishment in a tropical lowland wet forest. Biotropica 18:273-278

McGuire J, Mitchell R, Moser E (2001) Gaps in a gappy forest: plant resources, longleaf pine regeneration, and understory response to tree removal in longleaf pine savannas. Canadian Journal of Forest Research 31:765-778

McWilliam A, Roberts J, Cabral O, Leitao M, DeCosta A, Maitelli G, Zamparoni C (1993) Leaf area index and above-ground biomass of terra firme rain forest and adjacent clearings in Amazonia. Functional Ecology 7:310-317

Means J, Acker S, Harding D, Blair J, Lefsky M, Cohen W, Harmon M, McKee W (1999) Use of large-footprint scanning airborne LIDAR to estimate forest stand characteristics in the Western Cascades of Oregon. Remote Sensing of Environment 67:298-308

Monsi M, Saeki T (1953) Uber den Lichtfaktor in den Pflanzengesellschaften und seine Bedeutung fuer die Stoffproduktion. Japanese Journal of Botany 14:22-52

Nagamatsu D, Hirabuki Y, Mochida Y (2003) Influence of micro-landforms on forest structure, tree death and recruitment in a Japanese temperate mixed forest. Ecological Research 18:533-547

Nemani R, Keeling C, Hashimoto W, Jolly W, Piper S, Tucker C, Mynrni R, Running S (2003) Climate-driven increases in global terrestrial net primary production from 1982 to 1999 . Science 300:1560-1563 
Norman J, Campbell G (1989) Canopy structure. In: Pearcy R, Ehleringer J, Mooney H, Rundel P (eds) Plant physiological ecology. Field methods and instrumentation. Chapman \& Hall, London, UK

Norman F, Martin C (1993) Growth photosynthesis, water relations and competition of the old-field species Abutilon-theophrasti, Ambrosia-trifida, and helianthusannuus grown under controlled conditions. Photosynthetica 30:361-371

Orians GH (1982) The influence of tree-falls in tropical forests on tree species richness. Tropical Ecology 23:255-279

Ostertag R (1998) Belowground effects of canopy gaps in a tropical wet forest. Ecology 79:1294-1304

Pacala S, Canham C, Saponara J, Silander J, Kobe R, Ribbens E (1996) Forest models defined by field measurements: Estimation, error analysis and dynamics. Ecological Monographs 66:1-43

Palik B, Mitchell R, Houseal G, Pederson N (1997) Effects of canopy structure on resource availability and seedling responses in a longleaf pine ecosystem. Canadian Journal of Forest Research 27:1458-1464

Parker G (1995) Structure and microclimate of forest canopies. In: Lowman MD (eds) Forest Canopies. Academic Press Inc, San Diego, CA, pp 73-106

Parker G (2005) A portable LIDAR system for rapid determination of forest canopy structure. Journal of Applied Ecology 41:755-767

Parren M, Bongers F (2001) Does climber cutting reduce felling damage in southern Cameroon? Forest Ecology and Management 141:175-188

Pearcy R (1989) Radiation and light measurements. In: Pearcy R, Ehleringer J, Mooney HA, Rundel P (eds) Plant Physiological Ecology: Field methods and instrumentation. Chapman \& Hall, London, pp 95-116

Pierce L, Congalton R (1988) A methodology for mapping forest latent heat flux densities using remote sensing. Remote Sensing of Environment 24:405-418

Poorter L, Jans L, Bongers F, Van Rompaey R (1994) Spatial distribution of gaps along three catenas in the moist forest of Tai National Park, Ivory Coast. Journal of Ecology 10:385-398

Poorter L, Hayashida-Oliver Y (2000) Effect of seasonal drought on gap and understorey seedlings in a Bolivian moist forest. Journal of Tropical Ecology 16:481-498 
Reich P, Turner D, Bolstad P (1999) An approach to spatially distributed modeling of net primary production (NPP) and the landscape scale and its applications in validation of EOS NPP products. Remote Sensing of Environment 70:69-81

Reifsnyder W, Furnival G, Hororwitz J (1971) Spatial and temporal distribution of solar radiation beneath forest canopies. Agricultural and Forest Meteorology 9:21-37

Rich P, Clark D, Clark D, Oberbauer S (1993) Long-term study of solar radiation regimes in a tropical wet forest using quantum sensors and hemispherical photography. Agricultural and Forest Meteorology 65:107-127

Runkle J, Yetter T (1987) Treefalls revisited: Gap dynamics in the southern Appalachians. Ecology 68:417-424

Runkle JR (1981) Gap regeneration in some old-growth forests of the Eastern United States. Ecology 62:1041-1051

Runkle JR (1982) Patterns of disturbance in some old growth mesic forests of eastern North America. Ecology 63:1533-1546

Running S, Queen L, Thorton M (2000) The earth observing system and forest management. Journal of Forestry 98:29-31

Sancho F, Matta R (1987) Estudio detallado de suelos: Estacion Biologica 'La Selva'. Organization for Tropical Studies, San Jose, Costa Rica

Sanford RL, Braker EH, Hartshorn GS (1986) Canopy openings in a primary neotropical lowland forest. Journal of Tropical Ecology 2:277-282

Sanford RL, Paaby P, Luvall J, Philips E (1994) Climate, geomorphology, and aquatic systems. In: McDade L, Bawa K, Hespenheide H, Hartshorn G (eds) La Selva: Ecology and Natural History of a Neotropical Rain Forest. University of Chicago Press, Chicago, pp 19-33

Satake A, Iwasa Y, Hakoyama H (2004) Estimating local interaction from spatiotemporal forest data, and Monte Carlo bias correction. Journal of Theoretical Biology 226:225-235

Schemske D, Brokaw N (1981) Treefalls and the distribution of understory birds in a tropical forest. ecology 62:938-945

Schlicht R, Iwasa Y (2004) Forest gap dynamics and the Ising model. Journal of Theoretical Biology 230:65-75

Sellers P, Meeson B, Hall F (1995) Remote-sensing of the land-surface for studies of global change-models, alogarithms, experiments. Remote Sensing of Environment 
Schemske D, Brokaw N (1981) Treefalls and the distribution of understory birds in a tropical forest. ecology 62:938-945

Schlicht R, Iwasa Y (2004) Forest gap dynamics and the Ising model. Journal of Theoretical Biology 230:65-75

Sellers P, Meeson B, Hall F (1995) Remote-sensing of the land-surface for studies of global change-models, alogarithms, experiments. Remote Sensing of Environment $51: 3-26$

Shugart H, Smith T (1996) A review of forest patch models and their application to global change research. Climatic Change 34:131-153

Silver WL, Vogt KA (1993) Fine root dynamics following single and multiple disturbances in a subtropical wet forest ecosystem. Journal of Ecology 81:729738

Souza AF, Martins FR (2005). Spatial variation and dynamics of flooding, canopy openness and structure in a neotropical rain forest. Plant Ecology 180: 161-173

Spies TA, Franklin JF (1989) Gap characteristics and vegetation response in coniferous forests of the Pacific Northwest. Ecology 70:543-545

Sterck F, Bongers F (2001) Crown development in tropical rain forest trees: patterns with tree height and light availability. Journal of Ecology 89:1-13

Strong DR (1977) Epiphyte loads, tree falls, and perennial forest disruption: a mechanism for maintaining higher tree species richness in the tropics without animals. Journal of Biogeography 4:215-218

Tateno R, Takeda H (2003) Forest structure and tree species distribution in relation tot topography-mediated heterogeneity of soil nitrogen and light at the forest floor. Ecological Research 18:559-571

Taylor D, Saskena P, Sanderson PG, Kucera K (1999) Environmental change and rain forests on the Sunda shelf of Southeast Asia: drought, ,fire and the biological cooling of biodiversity hotspots. Biodiversity and Conservation 8:1159-1177

Ter Steege, H. Winphot 5: a program to analyze vegetation indices, light, and light quality from hemispherical photographs. Tropenbos Guyana Reports 95-2, Tropenbos Guyana Programme, Georgetown, Guyana 
Tutin CEG, White LJT, MackangaMissandzou A (1996) Lightning strike burns large forest tree in the Lope Reserve, Gabon. Global Ecology and Biogeography Letters $5: 36-41$

Uhl C, Murphy P (1981) Composition, structure, and regeneration of a tierra firme forest in the Amazon Basin of Venezuela. Tropical Ecology 22:219-237

Uhl C, Clark K, Dezzeo N (1988) Vegetation dynamics in Amazonian treefall gaps. Ecology 69:751-763

Valverde T, Silvertown J (1997) Canopy closure rate and forest structure. Ecology 78:1555-1562

Van Pelt R, Franklin J (1999) Response of understory trees to experimental gaps in oldgrowth Douglas-fir forests. Ecological Applications 9:504-512

VanderMeer PJ, Bongers F (1996a) Formation and closure of canopy gaps in the rain forest at Nourages, French Guiana. Vegetatio 126:167-179

VanderMeer PJ, Bongers F (1996b) Patterns of treefalls and branch falls in a tropical rain forest in French Guiana. Journal of Ecology 84:19-29

Vitusek PM, Denslow JS (1986) Nitrogen and phosphorus availability in treefall gaps of a lowland tropical forest. Journal of Ecology 74:1167-1178

Vose J, Swank W (1990) A conceptual model of forest growth emphasizing stand leaf area. In: Process modeling of forest growth responses to environmental stress. Timber Press, Portland, Oregon, pp 278-287

Waring R, Schlesinger W (1985) Forest ecosystems: concepts and management, New York

Wayne P, Bazzaz F (1993) Birch seedling responses to daily time courses of light in experimental forest gaps and shade houses. Ecology 74:1500-1515

Welles J, Norman J (1991) Instrument for indirect measurement of canopy architecture. Agronomical Journal 83:818-825

Whitmore TC (1989) Changes over twenty-one years in the Kolombangara west pacific ocean rain forests. Journal of Ecology 77:469-483

Whitmore TC, Brown N, Swaine M, Kennedy D, Goodwin-Bailey C, Gong W (1993) Use of hemispherical photographs in forest ecology: measurement of gap size and radiation totals in a Bornean tropical rain forest. Journal of Tropical Ecology $13: 131-151$ 
Williams RJ, Douglas M (1996) Windthrow in a tropical savanna in Kakadu National Park, Australia. Journal of Tropical Ecology 11:547-558

Wood T, Lawrence D, Clark D (2005) Variation in leaf litter nutrients of a Costa Rican rain forest is related to precipitation. Biogeochemistry 73:417-437

Young TP, Hubbel SP (1991) Crown asymmetry, treefalls, and repeat disturbance on broad-leaved forest gaps. Ecology 72:1464-1471 